\title{
Elagolix Treatment in Women With Heavy Menstrual Bleeding Associated With Uterine Fibroid: A Systematic Review and Meta-analysis
}

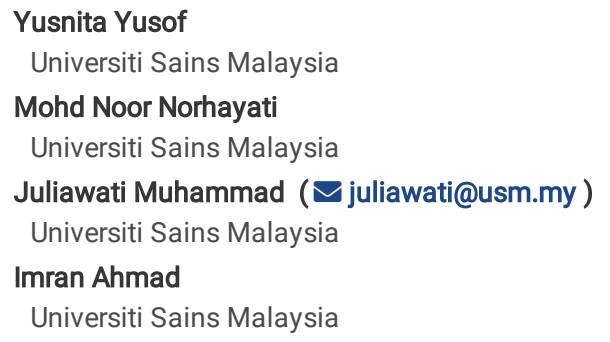

\section{Research Article}

Keywords: Elagolix, GnRH antagonist, Uterine fibroid, Leiomyoma, Heavy menstrual bleeding, Estradiol/norethindrone acetate

Posted Date: September 16th, 2021

DOI: https://doi.org/10.21203/rs.3.rs-770439/v1

License: (9) (1) This work is licensed under a Creative Commons Attribution 4.0 International License. Read Full License 


\section{Abstract}

Background: Elagolix is effective and safe for treating menorrhagia in women with uterine fibroid. However, it is reported to be associated with hypoestrogenism that can be alleviated by adding estradiol/norethindrone acetate. This systematic review and meta-analysis aimed to determine the effectiveness of elagolix treatment in women with heavy menstrual bleeding associated with uterine fibroid by comparing: elagolix versus placebo and elagolix versus estradiol/norethindrone acetate.

Methodology: The Cochrane Central Register of Controlled Trials (CENTRAL 2021, Issue 3 of 12), MEDLINE databases (1980 to December week 1, 2020), and trial registries for relevant randomized clinical trials were used. All randomized clinical trials were reviewed and evaluated. Random effects models were used to estimate the dichotomous outcomes and mean differences with $95 \%$ confidence intervals. Data for risk of bias, heterogeneity, sensitivity, reporting bias and quality of evidence were assessed.

Results: Four randomized controlled trials with 1949 premenopausal women from 323 locations were included. Elagolix improved menstrual blood loss of less than $80 \mathrm{ml}$ (RR 4.81, 95\% Cl 2.45 to 9.45; four trials, 869 participants; moderate quality evidence) or more than $50 \%$ reduction from baseline (RR 4.87 , $95 \%$ Cl 2.55 to 9.31 ; four trials, 869 participants; moderate quality evidence) compared to placebo. There was no difference in menstrual blood loss of less than $80 \mathrm{ml}$ (RR 1.08, 95\% Cl 1.00 to 1.16; five trials, 1365 participants; moderate quality evidence) or more than $50 \%$ reduction from baseline between the elagolix (RR $1.08,95 \% \mathrm{Cl} 1.01$ to 1.15; five trials, 1365 participants; high quality evidence) and elagolix with estradiol/norethindrone acetate. In both comparisons, elagolix has reduced the mean percentage change in uterine and fibroid volume, improved symptoms, and health-related quality of life. More patients had hot flush, and bone mineral density loss in the elagolix treatment compared to both placebo and elagolix with estradiol/norethindrone acetate.

Conclusions: Elagolix appeared to be effective in reducing heavy menstrual bleeding caused by uterine fibroid and combination with estradiol/norethindrone acetate was able to alleviate the hypoestrogenism side effects in premenopausal women.

Review registration. PROSPERO CDR 42021233898.

\section{Background}

Uterine fibroids are benign and noncancerous monoclonal tumor arising from smooth muscle cells and fibroblasts of the myometrium. It is believed that the specific growth factor receptor, hyper-estrogenic effect, angiogenesis disorder, and altered smooth muscle cell proliferation have a vital role in uterine fibroid growth (1). Most women are asymptomatic. If symptomatic, they may present with abnormal bleeding (e.g., heavy bleeding, prolonged bleeding or irregular periods), pelvic pain, and dyspareunia (2). The fibroids may also compromise reproductive functions, possibly contributing to subfertility, pregnancy outcomes, health related quality of life, economic burden, and work productivity (3-5).

The estimated prevalence of uterine fibroids increases with age and varies from 5.4-23.6\% during the reproductive years (6). The approximate prevalence of uterine fibroid was $33 \%$ based on clinical assessment, $50 \%$ with an ultrasound scan and $77 \%$ with histological examination of hysterectomy specimens (7). Treatments can be nonhormonal, hormonal pharmacological compounds, and surgical treatment. The surgical options include myomectomy, hysterectomy, endometrial uterine artery embolization, and endometrial ablation $(4,8,9)$.

Elagolix is a newly synthesized nonpeptidic gonadotrophin-releasing hormone (GnRH) receptor blocker that has been developed to treat endometriosis. It has recently received US FDA approval in July 2018 to manage moderate to severe pain associated with endometriosis (10). The elagolix also has given positive feedback or benefit in treating women with uterine fibroids by reducing pain and heavy menses. GnRH antagonist is a synthetic peptide structurally analogous to the natural $\mathrm{GnRH}$ hormones that bind to $\mathrm{GnRH}$ receptors causing gonadotropin suppression $(11-13)$. The circulating estrogen and progesterone level will be suppressed by shutting down the pituitary-ovarian axis. The suppression in steroid hormone level will cause the fibroid to shrink, reduce a significant menstrual blood loss, uterine volume, fibroid volume and achieve amenorrhea, which will later improve the hemoglobin level (8). It also reduces symptom severity and improves the health-related quality of life.

Other medical interventions include nonhormonal, hormonal medication, and surgical approaches that have been approved as beneficial in fibroid management. However, a certain treatment has limited usage due to substantial adverse effects of hypoestrogenism, e.g., hot flush, reduces bone mineral density, which is a risk factor of osteoporosis later on. Elagolix has a better adverse events profile. The addition of estradiol/norethindrone acetate to the treatment regime can prevent bone loss due to hypoestrogenic effect, which increases the safety of overall elagolix treatment (14).

A systematic evaluation of GnRH antagonist treatment in women with uterine fibroid is necessary to clarify its effectiveness or any adverse effects since it is known to have a better tolerable safety profile. This will give a beneficial outcome for the patients and eventually improve their quality of life. Elagolix may be a part of the clinical application as one option for treating symptomatic uterine fibroid effectively and reducing undesirable side effects.

Different dosages of elagolix were evaluated to determine its efficacy in reducing heavy and prolonged menstrual blood loss associated with uterine fibroid.

\section{Materials \& Methods}

We conducted this systematic review according to the protocol previously published in the PROSPERO register (https://www.crd.york.ac.uk/PROSPERO), [CDR42021233898]. The types of studies included were randomized control trials (RCTs) comparing elagolix with placebo or estradiol/norethindrone acetate. We included double-blinded studies.

\section{Eligibility criteria}


We included premenopausal women who had severe menstrual bleeding, identified as more than $80 \mathrm{~mL}$ of menstrual blood loss per menstrual cycle with uterine fibroids and confirmed by either transabdominal or transvaginal ultrasound. The type of intervention was elagolix compared to placebo or estradiol/norethindrone acetate. The primary outcome was the number of participants having a reduction of menstrual blood loss of less than $80 \mathrm{ml}$ or more than $50 \%$ in menstrual blood loss. Secondary outcomes were looking at improvement in hemoglobin level, uterine and fibroid volume, symptoms severity, health-related quality of life, bone mineral density and adverse events.

Heavy menstrual bleeding was defined as blood loss of or exceeding $80 \mathrm{ml}$ per menstrual cycle and measured by the standard validated alkaline hematin method (15-17). A 50\% cut-off point was chosen because blood comprised $50 \%$ of total menstrual flow in women with excessive menstrual blood loss of more than $100 \mathrm{ml}$ (18). The follow-up period for the primary outcome was at least twelve weeks after intervention. The primary outcome was measured during the last month of the treatment period.

\section{Search strategies}

Since 1980 was the year that gonadotropin-releasing hormone analogs were first adopted for medical use, we searched the Cochrane Central Register of Controlled Trials (CENTRAL 2021, Issue 3 of 12) and MEDLINE databases (1980 to December week 1, 2020). The keywords applied were (menorrhagia OR heavy menstrual bleeding OR abnormal uterine bleeding OR excessive menstrual bleeding) AND (fibroid OR leiomyoma OR fibroma OR fibromyoma) AND (elagolix OR GnRH antagonist). We used the search strategy in Additional File 1 to search MEDLINE, CENTRAL, and other databases. We restricted the publications to the English language only. We checked the reference list of identified randomized controlled trials and reviewed articles to find unpublished trials or trials not identified by electronic searches. We also contacted experts in the field and pharmaceutical companies that market elagolix to identify unpublished trials. We searched for ongoing trials through the World Health Organization International Clinical Trials Registry Platform https://www.who.int/ictrp/en and www.clinicaltrials.gov.

\section{Trial selection}

We scanned the titles and abstracts from the searches. We obtained full-text articles when they appear to meet the eligibility criteria, or insufficient information to assess the eligibility. We assessed the eligibility of the trials independently and documented the reasons for exclusion. We resolved any disagreements between the review authors by discussion. We contacted the authors if clarification was needed. We excluded papers in languages other than English.

\section{Data extraction}

We extracted data from each of the selected trials by using data extraction forms which include study setting, participant characteristics (age, sex, ethnicity), methodology (number of participants randomized and analyzed, duration of follow-up), dosage of elagolix, dosage of estradiol/norethindrone acetate, reduction of menstrual blood loss of less than $80 \mathrm{ml}$, reduction of more than $50 \%$ menstrual blood loss, uterine volume, fibroid volume, symptoms severity, health-related quality of life, haemoglobin level, bone mineral density, and adverse event medication (Additional File 3).

\section{Risk of bias assessment}

We assessed the risk of bias based on random sequence generation, allocation concealment, blinding of participants and personnel, blinding of outcome assessors, completeness of outcome data, the selectivity of outcome reporting and other bias (19). We resolved any disagreements by discussion. If there were sufficient studies, we intended to use funnel plots to assess the possibility of reporting biases or small study biases, or both.

\section{Statistical analysis}

We planned to undertake meta-analyses using Review Manager 5.4 software (20) and examined heterogeneity using a random-effects model to pool data. We measured the treatment effect for dichotomous outcomes using risk ratios and absolute risk reduction, and for continuous outcomes we used mean differences; both with $95 \%$ confidence intervals. We performed a sensitivity analysis to investigate the risk of bias for sequence generation and allocation concealment of included studies. We contacted the original trial authors to request missing or inadequately reported data. We performed analyses on the available data in the event that missing data was not available.

The planned subgroup analyses were dosage of elagolix and dosage of estradiol/norethindrone acetate. We were unable to carry out the subgroup dosage of elagolix as outlined in the protocol because there were insufficient trials. However, we conducted subgroup analyses on the frequency of drug administration either twice daily (bd) or once daily (qd) administration, uterine volume and fibroid volume.

\section{Assessment of heterogeneity}

We assessed the presence of heterogeneity in two steps. First, we assessed obvious heterogeneity at face value by comparing populations, settings, interventions, and outcomes. Second, we assessed statistical heterogeneity by means of the $\mathrm{I}^{2}$ statistic (19). The threshold for the interpretation of the $\mathrm{I}^{2}$ statistic can be misleading, since the importance of inconsistency depends on several factors. We planned to use the guide to interpretation of heterogeneity as outlined: $0-40 \%$ might not be important; $30-60 \%$ may represent moderate heterogeneity; $50-90 \%$ may represent substantial heterogeneity; and $75-100 \%$ would be considerable heterogeneity (19).

\section{Grading quality of evidence}

We assessed the quality of evidence for primary and secondary outcomes according to GRADE methodology (21) for risk of bias, inconsistency, indirectness, imprecision, and publication bias; classified as very low, low, moderate, or high. Quality can be downgraded depending on the presence of four factors: (i) limitations in the design and implementation of available studies; (ii) indirectness of evidence; (iii) unexplained heterogeneity or inconsistency of results; and (iv) imprecision of results. 


\section{Results}

\section{Results of the search}

We retrieved 139 records from the search of the electronic database and no other records from other sources (Fig. 1). A total of 94 records were screened after duplicates were removed. We reviewed full copies of 13 and assessed them for eligibility. We identified four articles as possibly meeting the review inclusion criteria, and nine of them were ineligible for inclusion. One article was a non-randomized controlled trial that evaluated the clinical response of elagolix-treated women who did not achieve the primary outcome (22). Two reviews, one on predictors of response to elagolix with add-back therapy and the other on medical treatment of uterine leiomyoma, were relevant to our research query $(4,23)$. There was no outcome of interest in the four papers as two papers $(3,11)$ on elagolix pharmacotherapy and pharmacodynamics and another two more papers $(14,24)$ on drug-drug interactions were written. Adenomyosis was the topic of two more publications $(25,26)$. We attempted to contact the trial authors for the full article but received no response. Therefore, we included four trials.

Table 1

Characteristics of included trial

\begin{tabular}{|c|c|c|c|c|c|c|c|c|c|}
\hline \multirow[t]{2}{*}{ Reference } & \multirow[t]{2}{*}{ Country } & \multicolumn{2}{|c|}{ Participants } & \multirow{2}{*}{$\begin{array}{l}\text { Inclusion } \\
\text { study period/ } \\
\text { Treatment } \\
\text { period }\end{array}$} & \multirow[t]{2}{*}{ Intervention } & \multirow{2}{*}{$\begin{array}{l}\text { Elagolix } \\
\text { dosage and } \\
\text { frequency } \\
\text { administration }\end{array}$} & \multirow[t]{2}{*}{ Comparator } & \multirow{2}{*}{$\begin{array}{l}\text { No of } \\
\text { participants/ } \\
\text { No of trial } \\
\text { sites }\end{array}$} & \multirow{2}{*}{$\begin{array}{l}\text { No of } \\
\text { missing }\end{array}$} \\
\hline & & $\begin{array}{l}\text { Age } \\
\text { group; } \\
\text { mean } \\
\text { baseline } \\
\text { MBL }\end{array}$ & $\begin{array}{l}\text { Mean baseline } \\
\text { uterine volume / } \\
\text { mean baseline } \\
\text { fibroid volume }\end{array}$ & & & & & & \\
\hline \multirow[t]{5}{*}{$\begin{array}{l}\text { Archer } \\
2017\end{array}$} & \multirow[t]{5}{*}{ USA } & \multirow{5}{*}{$\begin{array}{l}20-49 \\
\text { years; } \\
267 \mathrm{~mL}\end{array}$} & \multirow{5}{*}{$\begin{array}{l}535 \pm 389 \mathrm{~cm}^{3} / \\
91 \pm 175 \mathrm{~cm}^{3}\end{array}$} & \multirow{5}{*}{$\begin{array}{l}\text { September } \\
\text { 2011-May } \\
2014 \text { / } \\
3 \text { months }\end{array}$} & \multirow{5}{*}{$\begin{array}{l}\text { Elagolix } \\
\text { (ABT-620) }\end{array}$} & \multirow{5}{*}{$\begin{array}{l}\text { i; } 100 \text { mg bd } \\
\text { ii; } 200 \text { mg bd } \\
\text { iii; } 300 \text { mg bd } \\
\text { iv; } 400 \text { mg qd } \\
\text { v; } 600 \text { mg qd }\end{array}$} & \multirow{5}{*}{$\begin{array}{l}\text { i; placebo } \\
\text { (matching } \\
\text { placebo } \\
\text { tablet) } \\
\text { ii; } 0.5 \mathrm{mg} \\
\text { E2/0.1 md } \\
\text { NETA }\end{array}$} & \multirow[t]{5}{*}{$271 / 45$} & \multirow{5}{*}{$\begin{array}{l}\text { Intervention } \\
(29) \\
\text { Control } \\
(14)\end{array}$} \\
\hline & & & & & & & & & \\
\hline & & & & & & & & & \\
\hline & & & & & & & & & \\
\hline & & & & & & & & & \\
\hline \multirow[t]{4}{*}{ Carr 2018} & \multirow[t]{4}{*}{ USA } & \multirow{4}{*}{$\begin{array}{l}18-51 \\
\text { years; } \\
246 \pm 180 \\
\mathrm{~mL}\end{array}$} & \multirow{4}{*}{$\begin{array}{l}628 \pm 462 \mathrm{~cm}^{3} / \\
150 \pm 196 \mathrm{~cm}^{3}\end{array}$} & \multirow{4}{*}{$\begin{array}{l}\text { April 2013- } \\
\text { Dec 2015/ } 6 \\
\text { months }\end{array}$} & \multirow{4}{*}{$\begin{array}{l}\text { Elagolix } \\
\text { (ABT-620) }\end{array}$} & \multirow{4}{*}{$\begin{array}{l}\text { i; } 300 \text { mg bd } \\
\text { ii; } 600 \text { mg qd }\end{array}$} & & \multirow{4}{*}{$\begin{array}{l}571 * / 86 \\
\text { * } 4 \text { women } \\
\text { were } \\
\text { randomized } \\
\text { but not } \\
\text { treated }\end{array}$} & \multirow{4}{*}{$\begin{array}{l}\text { Intervention } \\
(32) \\
\text { Control } \\
(97)\end{array}$} \\
\hline & & & & & & & $\begin{array}{l}\text { (Oral } \\
\text { coated } \\
\text { placebo) }\end{array}$ & & \\
\hline & & & & & & & $\begin{array}{l}\mathrm{ii} ; 0.5 \mathrm{mg} \\
\text { E2/ } 0.1 \mathrm{mg} \\
\text { NETA }\end{array}$ & & \\
\hline & & & & & & & $\begin{array}{l}\mathrm{iii} ; 1.0 \mathrm{mg} \\
\text { E2/0.5 mg } \\
\text { NETA }\end{array}$ & & \\
\hline \multirow{7}{*}{$\begin{array}{l}\text { Schlaff } \\
2020\end{array}$} & \multirow[t]{7}{*}{ USA } & (UF-1) & (UF-1) & (UF-1) & Elagolix & \multirow[t]{7}{*}{$\mathrm{i} ; 300 \mathrm{mg}$ bd } & \multirow{7}{*}{$\begin{array}{l}\text { i; placebo } \\
\text { (film coated } \\
\text { placebo } \\
\text { tab) } \\
\text { ii; } 1.0 \mathrm{mg} \\
\text { E2/ } 0.5 \mathrm{mg} \\
\text { NETA }\end{array}$} & (UF-1) & (UF-1) \\
\hline & & $\begin{array}{l}18-51 \\
\text { years: }\end{array}$ & $482 \pm 393 \mathrm{~cm}^{3} /$ & $\begin{array}{l}\text { Dec 2015- } \\
\text { Dec 2018/ } 6\end{array}$ & (ABT-620) & & & 413 & Intervention \\
\hline & & & $50 \pm 68.9 \mathrm{~cm}^{3}$ & months & & & & (UF-2) & \\
\hline & & $\begin{array}{l}245 \pm 161 \\
\mathrm{~mL}\end{array}$ & (UF-2) & (UF-2) & & & & 378 & $\begin{array}{l}\text { Control } \\
(62)\end{array}$ \\
\hline & & (UF-2) & \multirow{3}{*}{$\begin{array}{l}519 \pm 437 \mathrm{~cm}^{3} / \\
63 \pm 111 \mathrm{~cm}^{3}\end{array}$} & Feb $2016-$ & & & & $/ 77$ & (UF-2) \\
\hline & & $\begin{array}{l}18-51 \\
\text { years; }\end{array}$ & & 6 months & & & & & $\begin{array}{l}\text { Intervention } \\
(26)\end{array}$ \\
\hline & & $\begin{array}{l}234 \pm 156 \\
\mathrm{~mL}\end{array}$ & & & & & & & $\begin{array}{l}\text { Control } \\
(63)\end{array}$ \\
\hline \multirow{3}{*}{$\begin{array}{l}\text { Simon } \\
2020 \\
\text { UF } \\
\text { EXTEND }\end{array}$} & USA & $\begin{array}{l}18-51 \\
\text { years; }\end{array}$ & $\begin{array}{l}519 \pm 457 \mathrm{~cm}^{3} / \\
59+97 \mathrm{~cm}^{3}\end{array}$ & $\begin{array}{l}\text { September } \\
2016-\text { Mac }\end{array}$ & Elagolix & $\mathrm{i} ; 300 \mathrm{mg}$ bd & $\begin{array}{l}\mathrm{i} ; 1.0 \mathrm{mg} \\
\mathrm{E} 2 / 0.5 \mathrm{mg}\end{array}$ & $\begin{array}{l}316 \text { out of } \\
433\end{array}$ & $\begin{array}{l}\text { Intervention } \\
\text { (19) }\end{array}$ \\
\hline & & $\begin{array}{l}236 \pm 159 \\
\mathrm{~mL}\end{array}$ & 泟 & $\begin{array}{l}2019 / \\
12 \text { months }\end{array}$ & $(\mathrm{ABT}-620)$ & & NETA & $\begin{array}{l}\text { recruited*/ } \\
115\end{array}$ & $\begin{array}{l}\text { Control } \\
(36)\end{array}$ \\
\hline & & & & & & & & $\begin{array}{l}\text { *117 } \\
\text { placebo } \\
\text { participants } \\
\text { exempted }\end{array}$ & \\
\hline
\end{tabular}

MBL-menstrual blood loss; UF-1 - elaris uterine fibroid-1; UF-2 - elaris uterine fibroid - 2; RCT-randomized controlled trial; USA-united states of America; bdtwice daily; qd-once daily; E2 - estradiol; NETA - norethindrone acetate

* 117 placebo participants in pivotal study (Schlaff 2020) exempted as not fulfills eligibility criteria; UF-EXTEND-Uterine Fibroid extend is an additional 6 month for total up to 12 -month treatment period.

Add-back therapy; elagolix with estradiol/norethindrone acetate 
Four randomized controlled trials with 1949 participants were included in the study (27-30). All four trials reported the primary outcome. All trials were sponsored by AbbVie (27-30).

\section{Participants}

All four studies were carried out in 323 locations across the United States, Puerto Rico, and Canada. One trial recruited participants from clinic settings (27). The other three trials did not mention the location from which participants were recruited (28-30). Three studies included premenopausal women aged 18 to 51 at the screening time (28-30), while one study recruited participants aged 20-49 (27). They underwent ultrasonography-confirmed diagnosis of uterine fibroids and heavy menstrual bleeding, as characterized by more than $80 \mathrm{ml}$ of menstrual blood loss per menstrual cycle for at least two cycles. The trials excluded participants due to a complex ovarian cyst, cancer, pelvic inflammatory disorder, osteoporosis history, or metabolic bone disease. Participants who had a myomectomy or hysterectomy for symptomatic uterine fibroid were exempted from the study $(27-30)$.

\section{Intervention}

Participants in the trials were randomized to the intervention and comparison groups. Two identical, double-blind, randomized, placebo-controlled, six-month phase 3 trials (Elaris Uterine Fibroids 1 and Elaris Uterine Fibroid 2) have been reported in one trial (29). Elaris Uterine Fibroid-1 and Elaris Uterine Fibroid-2 participants were later randomized or pooled into a new study (30) to look at the long-term twelve-month safety and efficacy of elagolix with or without estradiol/norethindrone acetate. The meta-analysis included four trials that evaluated the primary outcomes. Three trials compared elagolix with placebo (2729), and four trials compared to elagolix with estradiol/norethindrone acetate (27-30). Only one trial compared elagolix to placebo at different doses of 100 $\mathrm{mg} \mathrm{bd}, 200 \mathrm{mg} \mathrm{bd}, 300 \mathrm{mg}$ bd, $400 \mathrm{mg} \mathrm{qd}$, and $600 \mathrm{mg} \mathrm{qd}$ (27). One study was compared to placebo at doses of $300 \mathrm{mg}$ bd and $600 \mathrm{mg}$ qd (28). Another trial was compared elagolix to placebo at a dose of $300 \mathrm{mg} \mathrm{bd}(29)$.

In a comparison of elagolix to elagolix with estradiol/norethindrone acetate, one trial compared it at a dose of $0.5 \mathrm{mg}$ estradiol/ $0.1 \mathrm{mg}$ norethindrone acetate (27), while two trials compared it at a dose of $1.0 \mathrm{mg}$ estradiol/ $0.5 \mathrm{mg}$ norethindrone acetate $(29,30)$. In one trial, elagolix was compared to elagolix with estradiol/norethindrone acetate at two doses: $0.5 \mathrm{mg}$ estradiol $/ 0.1 \mathrm{mg}$ norethindrone acetate and $1.0 \mathrm{mg}$ estradiol/0.5 mg norethindrone acetate (28). All medications are taken orally as tablets or capsules. The duration of treatment differed between trials compared to elagolix versus placebo, as only one trial was three months $(27)$, and the other two trials were six months $(28,29)$. In contrast, the length of treatment differed between trials when comparing elagolix to elagolix with estradiol/norethindrone acetate, with a three-month $(27)$, a six-month $(28,29)$, and a twelve-month $(30)$ period.

\section{Outcomes}

The validated alkaline hematin method was used to quantify and evaluate the primary outcome in all four trials (27-30). Any spotting or bleeding episodes on a sanitary pad were reported at the time of screening or during treatment. Participants kept an electronic daily bleeding diary (eDiary) and assessed bleeding patterns using the validated Mansfield-Voda-Jorgenson Menstrual Bleeding Scale (31). All studies were followed up to at least three-months duration. The primary outcome was measured during the last month of the treatment period.

All four trials reported all secondary outcomes except for one study (27), which did not record bone mineral density due to a limited study time and a small sample size per group. Reduction of uterine and fibroid volume was calculated using trans abdominal or transvaginal ultrasound. The mean percentage change from baseline to the end of the treatment month was recorded.

The Uterine Fibroid Symptom and Quality of Life questionnaire's cumulative score were used to measure symptom severity reduction and change in healthrelated quality of life in women with symptomatic uterine fibroids. It was a disease-specific, self-administered, validated questionnaire. There were 37 questions in all, split into two parts. The first part consisted of an 8-item symptom severity scale. The second part consisted of a 29 -item health-related quality of life subscale with six domains (concern, behaviors, energy/mood, power, self-consciousness, and sexual function). All items are rated on a 5-point scale, with symptom intensity items ranging from "not at all" to "a great deal", and health-related quality of life items ranging from "none of the time" to "all of the time". The cumulative score for each of the two components was determined by adding the symptom intensity and health-related quality of life subscale scores and translating them to a 0-to-100-point scale. Higher overall health-related quality of life scores indicated better quality of life, while lower symptom severity scores indicate better quality of life.

The percentage of increase in hemoglobin concentration from baseline to the last month of treatment was reported in all trials. Loss of bone mineral density was assessed by dual-energy $\mathrm{x}$-ray absorptiometry scans of the lumbar spine, total hip, and femoral neck. The mean percentage change in bone mineral density from baseline to the last month of treatment was recorded in three studies (28-30). Any adverse events were recorded beginning with the first dose of the study drug and continuing for up to 30 days after completing the last dose of the study drug. All four trials identified common adverse events such as hot flushes, headaches, nausea, and fatigue. In this review, only two trials documented adverse events such as abdominal pain, dizziness, and hypertension (27, 28). Other non-significant adverse events identified in clinical trials will not be addressed in this review.

\section{Risk of bias in included studies}

The assessment risk of bias is shown in Fig. 2 and Fig. 3. Figure 2 shows the proportion of studies assessed as low, high or unclear risk of bias for each risk of bias indicator. Figure 3 shows the risk of bias indicators for individual studies. The details of these trials are found in the table of characteristics of included studies (Table 1).

\section{Allocation}

Only one trial, with 271 participants, was reported to have been recruited in a clinic setting, while the other three were not (27). The method of randomization was not reported in all four trials (27-30). Thus, we judged random sequence generation as having an unclear risk of bias. Allocation concealment was not mentioned and regarded as unclear in four trials $(27-30)$. 


\section{Blinding}

Participants, care provider, investigator and outcome assessor were masked in all four trials. The details on blinding were not recorded in all four trials, but the outcomes were unlikely to be influenced as it was objectively collected and measured using standardized methods (27-30). Therefore, they are judged as having a low risk of bias.

\section{Incomplete outcome data}

More than $80 \%$ of participants completed the studies in two trials $(27,30)$. Meanwhile, $74.4 \%$ of participants in one trial completed the study (28). Approximately 129 of the 571 participants failing to complete the analysis due to hypoestrogenism side effects $(n=39)$, withdrawal $(n=38)$, loss of follow up $(n=25)$, noncompliance $(n=11)$, lack of efficacy $(n=3)$, surgery $(n=4)$ and other $(n=9)(28)$. About $78 \%$ of 791 participants completed studies in Elaris Uterine Fibroid-1 and Elaris Uterine Fibroid-2 (29). The study drug was discontinued by similar proportions of women in both treatment groups (16.5\% for elagolix with estradiol/norethindrone acetate and $19.4 \%$ for elagolix alone), with the most common primary reason being lost to follow-up (5.0\% and $5.1 \%$, respectively) in one trial (29). Missing data were evenly balanced across groups, and the reasons were similar. The most common reasons for missing outcome data included withdrawal, noncompliance, loss to follow up, hypoestrogenism side effects, pregnancy, and surgery, which led to discontinuation. Selective reporting

All four trials reported the outcomes as specified in their methods Sect. (27-30). The outcomes listed in the registered protocol were those reported. Although changes in bone mineral density were assessed as an exploratory parameter, one trial did not report due to the short duration of the study and the relatively small sample size per group (27). We graded it as having a low risk of bias.

\section{Other potential source of bias}

We discovered that women with asymptomatic anemia and a hemoglobin level of less than $12 \mathrm{~g} / \mathrm{dl}$ at screening or during the study period were advised to take iron supplements in two trials $(27,30)$. This could have an influence on the hemoglobin level at the end of the treatment period. Thus, we judged it as having a high risk of bias. We detected no other potential source of bias in the other two trials $(28,29)$.

\section{Effects of intervention}

There would be two comparisons evaluated in this review, i.e., comparing elagolix versus placebo and comparing elagolix versus estradiol/norethindrone acetate.

\section{A) Comparison between elagolix and placebo}

Elagolix has increased the number of patients with a reduction of menstrual blood loss of less than $80 \mathrm{ml}\left(\mathrm{RR} 4.81,95 \% \mathrm{Cl} 2.45\right.$ to $9.45 ; \mathrm{I}^{2}$ statistic $=89 \%$; $\mathrm{P}<$ 0.001; four trials, 869 participants; moderate quality evidence) (Fig. 4, Table 2) (27-29) or more than $50 \%$ from baseline (RR $4.87,95 \%$ Cl 2.55 to 9.31 ; ${ }^{2}$ statistic $=87 \% ; \mathrm{P}<0.001$; four trials, 869 participants; moderate quality evidence) (Fig. 5, Table 2) (27-29) compared to placebo. The sensitivity analysis did not change the cumulative effect estimate. Table 3 showed the subgroup analysis for reduction of menstrual blood loss of less than $80 \mathrm{ml}$ or more than $50 \%$ reduction from baseline stratified by frequency of drug administration, uterine and fibroid volume (Additional File 1). 
Table 2

Summary of findings including GRADE quality assessment for comparison between elagolix and placebo

\begin{tabular}{|c|c|c|c|c|c|c|c|c|c|c|c|}
\hline \multicolumn{7}{|c|}{ Certainty assessment } & \multicolumn{2}{|c|}{ No of patients } & \multicolumn{2}{|l|}{ Effect } & \multirow[t]{2}{*}{ Certain } \\
\hline $\begin{array}{l}\text { No of } \\
\text { studies }\end{array}$ & $\begin{array}{l}\text { Study } \\
\text { design }\end{array}$ & $\begin{array}{l}\text { Risk of } \\
\text { bias }\end{array}$ & Inconsistency & Indirectness & Imprecision & $\begin{array}{l}\text { Other } \\
\text { consideration }\end{array}$ & Elagolix & Placebo & $\begin{array}{l}\text { Relative } \\
\text { (95\% } \\
\text { Cl) }\end{array}$ & $\begin{array}{l}\text { Absolute } \\
(95 \% \mathrm{Cl})\end{array}$ & \\
\hline \multicolumn{12}{|c|}{ Reduction of menstrual blood loss of less than $80 \mathrm{ml}$} \\
\hline 4 & $\begin{array}{l}\text { Randomized } \\
\text { trials }\end{array}$ & $\begin{array}{l}\text { not } \\
\text { serious } \\
\text { a }\end{array}$ & serious $^{b}$ & not serious & not serious & none & $\begin{array}{l}414 / 485 \\
(85.4 \%)\end{array}$ & $\begin{array}{l}80 / 834 \\
(20.8 \%)\end{array}$ & $\begin{array}{l}\text { RR } 4.81 \\
(2.45 \text { to } \\
9.45)\end{array}$ & $\begin{array}{l}794 \\
\text { more per } \\
1,000 \\
\text { (from } \\
302 \\
\text { more to } \\
1,000 \\
\text { more) }\end{array}$ & $\begin{array}{l}\oplus \bigoplus \bigoplus \\
\text { MODEF }\end{array}$ \\
\hline \multicolumn{12}{|c|}{ Reduction of more than $50 \%$ menstrual blood loss } \\
\hline 4 & $\begin{array}{l}\text { Randomized } \\
\text { trials }\end{array}$ & $\begin{array}{l}\text { not } \\
\text { serious }\end{array}$ & serious ${ }^{c}$ & not serious & not serious & none & $\begin{array}{l}416 / 485 \\
(85.8 \%)\end{array}$ & $\begin{array}{l}78 / 384 \\
(20.3 \%)\end{array}$ & $\begin{array}{l}\text { RR } 4.87 \\
(2.55 \text { to } \\
9.31)\end{array}$ & $\begin{array}{l}362 \\
\text { more per } \\
1,000 \\
\text { (from } \\
231 \\
\text { more to } \\
528 \\
\text { more) }\end{array}$ & $\begin{array}{l}\oplus \bigoplus \bigoplus \\
\text { MODEF }\end{array}$ \\
\hline
\end{tabular}

Improvement in hemoglobin level

\begin{tabular}{|c|c|c|c|c|c|c|c|c|c|c|c|}
\hline 4 & $\begin{array}{l}\text { Randomized } \\
\text { trials }\end{array}$ & $\begin{array}{l}\text { not } \\
\text { serious }\end{array}$ & not serious & not serious & serious & none & $\begin{array}{l}196 / 320 \\
(61.3 \%)\end{array}$ & $\begin{array}{l}58 / 234 \\
(24.8 \%)\end{array}$ & $\begin{array}{l}\text { RR } 2.46 \\
(1.93 \text { to } \\
3.13)\end{array}$ & $\begin{array}{l}786 \\
\text { more per } \\
1,000 \\
\text { (from } \\
315 \\
\text { more to } \\
1,000 \\
\text { more) }\end{array}$ & $\begin{array}{l}\oplus \bigoplus \bigoplus \\
\text { MODEF }\end{array}$ \\
\hline \multicolumn{12}{|c|}{ Adverse event (Hot flush) } \\
\hline 4 & $\begin{array}{l}\text { Randomized } \\
\text { trials }\end{array}$ & $\begin{array}{l}\text { not } \\
\text { serious }\end{array}$ & not serious ${ }^{e}$ & not serious & serious $^{d}$ & none & $\begin{array}{l}259 / 501 \\
(51.7 \%)\end{array}$ & $\begin{array}{l}25 / 389 \\
(6.4 \%)\end{array}$ & $\begin{array}{l}\text { RR } 7.47 \\
\text { (4.99 to } \\
11.18)\end{array}$ & $\begin{array}{l}416 \\
\text { more per } \\
1,000 \\
\text { (from } \\
256 \\
\text { more to } \\
654 \\
\text { more) }\end{array}$ & $\begin{array}{l}\oplus \oplus \bigoplus \\
\text { MODEF }\end{array}$ \\
\hline \multicolumn{12}{|c|}{ Uterine volume } \\
\hline 4 & $\begin{array}{l}\text { Randomized } \\
\text { trials }\end{array}$ & $\begin{array}{l}\text { not } \\
\text { serious }\end{array}$ & serious $^{f}$ & not serious & not serious & none & 424 & 359 & - & $\begin{array}{l}\text { MD } 34.5 \\
\text { lower } \\
\text { (43.48 } \\
\text { lower to } \\
25.53 \\
\text { lower) }\end{array}$ & $\begin{array}{l}\oplus \oplus \bigoplus \\
\text { MODEF }\end{array}$ \\
\hline \multicolumn{12}{|c|}{ Fibroid volume } \\
\hline 4 & $\begin{array}{l}\text { Randomized } \\
\text { trials }\end{array}$ & $\begin{array}{l}\text { not } \\
\text { serious }\end{array}$ & serious ${ }^{g}$ & not serious & not serious & none & 406 & 344 & - & $\begin{array}{l}\text { MD } \\
31.39 \\
\text { lower } \\
\\
\text { (44.69 } \\
\text { lower to } \\
18.09 \\
\text { lower) }\end{array}$ & $\begin{array}{l}\oplus \bigoplus \bigoplus \\
\text { MODEF }\end{array}$ \\
\hline \multicolumn{12}{|c|}{ Symptom severity } \\
\hline 4 & $\begin{array}{l}\text { Randomized } \\
\text { trials }\end{array}$ & $\begin{array}{l}\text { not } \\
\text { serious }\end{array}$ & very serious ${ }^{h}$ & not serious & not serious & none & 445 & 369 & - & $\begin{array}{l}\mathrm{MD} \\
31.54 \\
\text { lower } \\
\\
\text { (41.85 } \\
\text { lower to } \\
21.22 \\
\text { lower) }\end{array}$ & $\begin{array}{l}\oplus \oplus 0 \\
\text { LOW }\end{array}$ \\
\hline
\end{tabular}




\begin{tabular}{|c|c|c|c|c|c|c|c|c|c|c|c|}
\hline \multicolumn{7}{|c|}{ Certainty assessment } & \multicolumn{2}{|c|}{ No of patients } & \multicolumn{2}{|l|}{ Effect } & \multirow[t]{2}{*}{ Certain } \\
\hline $\begin{array}{l}\text { No of } \\
\text { studies }\end{array}$ & $\begin{array}{l}\text { Study } \\
\text { design }\end{array}$ & $\begin{array}{l}\text { Risk of } \\
\text { bias }\end{array}$ & Inconsistency & Indirectness & Imprecision & $\begin{array}{l}\text { Other } \\
\text { consideration }\end{array}$ & Elagolix & Placebo & $\begin{array}{l}\text { Relative } \\
\text { (95\% } \\
\text { Cl) }\end{array}$ & $\begin{array}{l}\text { Absolute } \\
(95 \% \mathrm{Cl})\end{array}$ & \\
\hline \multicolumn{12}{|c|}{ Health-related quality of life } \\
\hline \multirow[t]{3}{*}{4} & \multirow{3}{*}{$\begin{array}{l}\text { Randomized } \\
\text { trials }\end{array}$} & \multirow{3}{*}{$\begin{array}{l}\text { not } \\
\text { serious }\end{array}$} & \multirow[t]{3}{*}{ very serious } & \multirow[t]{3}{*}{ not serious } & \multirow[t]{3}{*}{ not serious } & \multirow[t]{3}{*}{ none } & \multirow[t]{3}{*}{443} & \multirow[t]{3}{*}{369} & \multirow[t]{3}{*}{-} & \multirow{2}{*}{$\begin{array}{l}\text { MD } \\
30.64 \\
\text { higher }\end{array}$} & $\oplus \oplus$ \\
\hline & & & & & & & & & & & LOW \\
\hline & & & & & & & & & & $\begin{array}{l}\text { (20.14 } \\
\text { higher to } \\
41.15 \\
\text { higher) }\end{array}$ & \\
\hline \multicolumn{12}{|c|}{ Bone mineral density (Lumbar spine) } \\
\hline \multirow[t]{2}{*}{3} & \multirow{2}{*}{$\begin{array}{l}\text { Randomized } \\
\text { trials }\end{array}$} & \multirow{2}{*}{$\begin{array}{l}\text { Not } \\
\text { serious }\end{array}$} & \multirow[t]{2}{*}{ Not serious } & \multirow[t]{2}{*}{ Not serious } & \multirow[t]{2}{*}{ Serious } & \multirow[t]{2}{*}{ none } & \multirow[t]{2}{*}{281} & \multirow[t]{2}{*}{293} & \multirow[t]{2}{*}{-} & \multirow{2}{*}{$\begin{array}{l}\text { MD } 2.82 \\
\text { lower } \\
(3.3 \\
\text { lower to } \\
2.35 \\
\text { lower) }\end{array}$} & $\oplus \oplus \bigoplus$ \\
\hline & & & & & & & & & & & MODEF \\
\hline \multicolumn{12}{|c|}{ Bone mineral density (Total hip) } \\
\hline \multirow[t]{2}{*}{3} & \multirow{2}{*}{$\begin{array}{l}\text { Randomized } \\
\text { trials }\end{array}$} & \multirow{2}{*}{$\begin{array}{l}\text { Not } \\
\text { serious }\end{array}$} & \multirow[t]{2}{*}{ Not serious } & \multirow[t]{2}{*}{ Not serious } & \multirow[t]{2}{*}{ Serious } & \multirow[t]{2}{*}{ none } & 281 & 293 & - & MD 1.97 & $\oplus \bigoplus \bigoplus$ \\
\hline & & & & & & & & & & $\begin{array}{l}\text { lower to } \\
1.57 \\
\text { lower) }\end{array}$ & MODEF \\
\hline Bone mir & eral density ( $\mathrm{Fe}$ & noral necl & & & & & & & & & \\
\hline 3 & $\begin{array}{l}\text { Randomized } \\
\text { trials }\end{array}$ & $\begin{array}{l}\text { Not } \\
\text { serious }\end{array}$ & Not serious & Not serious & Serious & none & 281 & 293 & - & $\begin{array}{l}\text { MD } 1.92 \\
\text { lower }\end{array}$ & $\oplus \bigoplus \bigoplus$ \\
\hline & & & & & & & & & & $\begin{array}{l}(2.61 \\
\text { lower to } \\
1.23 \\
\text { lower) }\end{array}$ & MODEF \\
\hline
\end{tabular}


Table 3

Summary of findings, including GRADE quality assessment for the comparison between elagolix and placebo by subgroup analysis

\begin{tabular}{|c|c|c|c|c|c|c|c|c|}
\hline \multicolumn{2}{|l|}{ Outcome/Subgroup } & $\begin{array}{l}\text { No of } \\
\text { trials }\end{array}$ & $\begin{array}{l}\text { No of } \\
\text { participants }\end{array}$ & $\begin{array}{l}\text { Risk Ratio } \\
\text { (RR) }\end{array}$ & $\begin{array}{l}\text { 95\% Confidence } \\
\text { interval (Cl) }\end{array}$ & $\begin{array}{l}P \\
\text { value }\end{array}$ & $\begin{array}{l}\text { Random effect; }\left.\right|^{2} \\
\text { statistic }\end{array}$ & $\begin{array}{l}\text { GRADE } \\
\text { quality }\end{array}$ \\
\hline \multicolumn{9}{|c|}{ Reduction of menstrual blood loss of less than $80 \mathrm{ml}$} \\
\hline \multirow[t]{2}{*}{$\begin{array}{l}\text { Frequency of drug } \\
\text { administration }\end{array}$} & $\begin{array}{l}\text { Twice a day } \\
\text { (bd) }\end{array}$ & 4 & 663 & 4.90 & $2.59,9.25$ & $\begin{array}{l}\mathrm{P}< \\
0.001\end{array}$ & $84 \%$ & Low \\
\hline & $\begin{array}{l}\text { Once a day } \\
\text { (qd) }\end{array}$ & 2 & 223 & 3.35 & $1.28,8.78$ & $\begin{array}{l}P= \\
0.010\end{array}$ & $59 \%$ & Low \\
\hline \multirow[t]{2}{*}{ Uterine volume } & $<500 \mathrm{~cm}^{3}$ & 2 & 311 & 8.75 & $4.97,15.42$ & $\begin{array}{l}P< \\
0.001\end{array}$ & $0 \%$ & Moderate \\
\hline & $>500 \mathrm{~cm}^{3}$ & 3 & 558 & 3.66 & $1.96,6.83$ & $\begin{array}{l}P< \\
0.001\end{array}$ & $84 \%$ & Very low \\
\hline \multirow[t]{2}{*}{ Fibroid volume } & $<50 \mathrm{~cm}^{3}$ & 2 & 252 & 8.77 & $4.98,15.45$ & $\begin{array}{l}P< \\
0.001\end{array}$ & $0 \%$ & Moderate \\
\hline & $>50 \mathrm{~cm}^{3}$ & 3 & 632 & 3.85 & $2.09,7.09$ & $\begin{array}{l}P< \\
0.001\end{array}$ & $84 \%$ & Very low \\
\hline \multicolumn{9}{|c|}{ Reduction of more than $50 \%$ menstrual blood loss } \\
\hline \multirow[t]{2}{*}{$\begin{array}{l}\text { Frequency of drug } \\
\text { administration }\end{array}$} & $\begin{array}{l}\text { Twice a day } \\
\text { (bd) }\end{array}$ & 4 & 663 & 5.00 & $2.74,9.13$ & $\begin{array}{l}P< \\
0.001\end{array}$ & $82 \%$ & Low \\
\hline & $\begin{array}{l}\text { Once a day } \\
\text { (qd) }\end{array}$ & 2 & 221 & 2.47 & $1.87,3.26$ & $\begin{array}{l}P< \\
0.001\end{array}$ & $0 \%$ & Moderate \\
\hline \multirow[t]{2}{*}{ Uterine volume } & $<500 \mathrm{~cm}^{3}$ & 2 & 311 & 8.75 & $4.97,15.42$ & $\begin{array}{l}P< \\
0.001\end{array}$ & $0 \%$ & Moderate \\
\hline & $>500 \mathrm{~cm}^{3}$ & 3 & 558 & 3.75 & $2.06,6.82$ & $\begin{array}{l}P< \\
0.001\end{array}$ & $82 \%$ & Very low \\
\hline \multirow[t]{2}{*}{ Fibroid volume } & $<50 \mathrm{~cm}^{3}$ & 2 & 252 & 4.66 & $0.92,21.71$ & $\begin{array}{l}P= \\
0.060\end{array}$ & $92 \%$ & Very low \\
\hline & $>50 \mathrm{~cm}^{3}$ & 3 & 632 & 3.92 & $2.19,7.03$ & $\begin{array}{l}\mathrm{P}< \\
0.001\end{array}$ & $82 \%$ & Very low \\
\hline
\end{tabular}

For the secondary outcomes, elagolix has increased the number of patients with improved hemoglobin level $\left(\mathrm{RR} 2.46,95 \% \mathrm{Cl} 1.93\right.$ to $3.13 ; \mathrm{I}^{2}$ statistic $=0 \% ; \mathrm{P}<$ 0.001; four trials, 554 participants; moderate quality evidence) (27-29), reduced the mean percentage change in uterine volume (MD $-34.50,95 \% \mathrm{Cl}-43.48$ to -25.53 ; $I^{2}$ statistic = 63\%; $\mathrm{P}<0.001$; four trials, 783 participants; moderate quality evidence) (27-29), fibroid volume (MD $-31.39,95 \% \mathrm{Cl}-44.69$ to $-18.09 ; I^{2}$ statistic $=65 \% ; \mathrm{P}<0.001$; four trials, 750 participants; moderate quality evidence) (27-29), severity of symptoms (MD $-31.54,95 \% \mathrm{Cl}-41.85$ to $-21.22 ;{ }^{2}$ statistic $=96 \% ; \mathrm{P}<0.001$; four trials, 814 participants; low quality evidence) (27-29), and improved health-related quality of life (MD $30.64,95 \% \mathrm{Cl} 20.14$ to 41.15; $I^{2}$ statistic = 95\%; $\mathrm{P}<0.001$; four trials, 812 participants; low quality evidence) (27-29) (Additional File 1, Table 2) compared to placebo.

Elagolix has reduced bone mineral density in lumbar spine (MD $-2.82,95 \% \mathrm{Cl}-3.30$ to $-2.35 ; \mathrm{I}^{2}$ statistic $=0 \%$; $\mathrm{P}<0.001$; three trials, 574 participants; moderate quality evidence) $(28,29)$, total hip (MD $-1.97,95 \% \mathrm{Cl}-2.37$ to -1.57 ; $\left.\right|^{2}$ statistic $=46 \%$; $\mathrm{P}<0.001$; three trials, 574 participants; moderate quality evidence) $(28$, 29) and femoral neck (MD -1.92, 95\% Cl-2.61 to -1.23 ; $\mathrm{I}^{2}$ statistic $=34 \%$; $\mathrm{P}<0.001$; three trials, 574 participants; moderate quality evidence) (28, 29) (Fig. 6 , Table 2) compared to placebo.

There was no significant of severe, serious or adverse event led to discontinuation of elagolix treatment. Elagolix has increased the number of patients with side effect of hot flush (RR 7.47, 95\% Cl 4.99 to 11.18; $I^{2}$ statistic $=8 \% ; \mathrm{P}<0.001$; four trials, 890 participants; moderate quality evidence) (27-29) and headache (RR $1.88,95 \% \mathrm{Cl} 1.25$ to $2.83 ; \mathrm{I}^{2}$ statistic $=0 \%$; $<$ < 0.001; four trials, 890 participants; low quality evidence) (27-29) (Fig. 7, Table 4) compared to placebo. 
Table 4

Summary of findings, including GRADE quality assessment for the comparison between elagolix and placebo by adverse events

\begin{tabular}{|c|c|c|c|c|c|c|c|}
\hline Adverse event & $\begin{array}{l}\text { No of } \\
\text { trials }\end{array}$ & $\begin{array}{l}\text { No of } \\
\text { participants }\end{array}$ & $\begin{array}{l}\text { Risk Ratio } \\
\text { (RR) }\end{array}$ & $\begin{array}{l}95 \% \text { Confidence interval } \\
\text { (Cl) }\end{array}$ & $P$ value & $\begin{array}{l}\text { Random effect; }\left.\right|^{2} \\
\text { statistic }\end{array}$ & $\begin{array}{l}\text { GRADE } \\
\text { quality }\end{array}$ \\
\hline Any $A E$ & 4 & 890 & 1.25 & $1.15,1.36$ & $\begin{array}{l}P< \\
0.001\end{array}$ & $0 \%$ & High \\
\hline Serious AE & 4 & 890 & 0.93 & $0.48,1.81$ & $\begin{array}{l}P= \\
0.830\end{array}$ & $0 \%$ & Low \\
\hline Severe AE & 3 & 605 & 1.53 & $0.86,2.73$ & $\begin{array}{l}P= \\
0.150\end{array}$ & $0 \%$ & Low \\
\hline $\begin{array}{l}\text { AE led to } \\
\text { discontinuation }\end{array}$ & 4 & 890 & 1.66 & $1.05,2.64$ & $\begin{array}{l}P= \\
0.030\end{array}$ & $0 \%$ & Low \\
\hline Hot flush & 4 & 890 & 7.47 & $4.99,11.18$ & $\begin{array}{l}P< \\
0.001\end{array}$ & $8 \%$ & Moderate \\
\hline Headache & 4 & 890 & 1.88 & $1.25,2.83$ & $\begin{array}{l}P= \\
0.003\end{array}$ & $0 \%$ & Low \\
\hline Abdominal pain & 2 & 495 & 1.17 & $0.37,3.66$ & $\begin{array}{l}P= \\
0.790\end{array}$ & $6 \%$ & Low \\
\hline Dizziness & 2 & 495 & 1.26 & $0.48,3.29$ & $\begin{array}{l}P= \\
0.640\end{array}$ & $18 \%$ & Low \\
\hline Nausea & 4 & 890 & 1.00 & $0.53,1.92$ & $\begin{array}{l}P= \\
0.990\end{array}$ & $41 \%$ & Low \\
\hline Fatigue & 4 & 890 & 0.77 & $0.33,1.79$ & $\begin{array}{l}P= \\
0.550\end{array}$ & $0 \%$ & Low \\
\hline Hypertension & 2 & 495 & 1.25 & $0.14,10.93$ & $\begin{array}{l}P= \\
0.840\end{array}$ & * & Low \\
\hline
\end{tabular}

\section{B) Comparison between elagolix and elagolix with estradiol/norethindrone acetate}

There was no difference in menstrual blood loss of less than $80 \mathrm{ml}$ (RR 1.08, 95\% Cl 1.00 to 1.16; $\left.\right|^{2}$ statistic $=56 \%$; P = 0.070; five trials, 1365 participants; moderate quality evidence) (Fig. 8, Table 5) (27-30) or more than $50 \%$ reduction from baseline between the elagolix $\left(\mathrm{RR} 1.08,95 \% \mathrm{Cl} 1.01\right.$ to $1.15 ; \mathrm{I}^{2}$ statistic $=$ $43 \%$; $=0.020$; five trials, 1365 participants; high quality evidence) (Fig. 9, Table 5) (27-30) and elagolix with estradiol/norethindrone acetate. The sensitivity analysis did not change the cumulative effect estimate. Table 6 showed the subgroup analysis for reduction of menstrual blood loss of less than $80 \mathrm{ml}$ or more than $50 \%$ reduction from baseline stratified by dosage and uterine volume (Additional File 1 ). 
Table 5

Summary of findings, including GRADE quality assessment for the comparison between elagolix and elagolix with estradiol/norethindrone acetate

Certainty assessment
No of patients

Elagolix

Other bias

Indirectness
Study

design studies

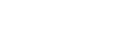

Reduction of menstrual blood loss less than $80 \mathrm{ml}$

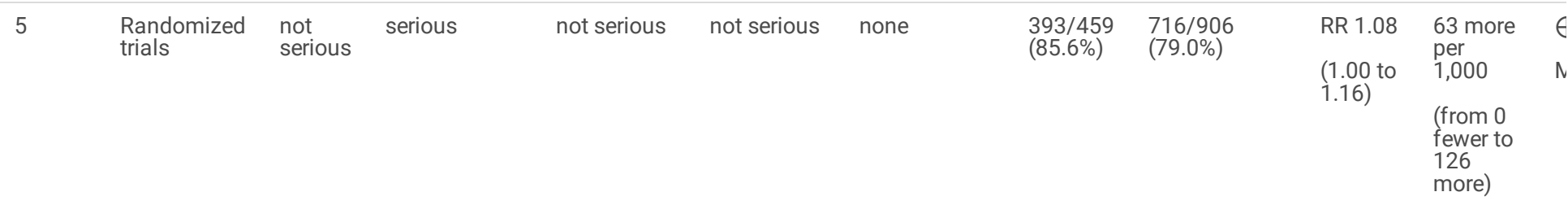

Effect

Relative Absolute (95\% $\quad(95 \% \mathrm{Cl})$ estradiol plus $(95 \%$ norethindrone Cl) acetate

Reduction of more than $50 \%$ menstrual blood loss

$\begin{array}{ll}\text { RR 1.08 } & 63 \text { more } \\ & \text { per } \\ (1.00 \text { to } & 1,000 \\ 1.16) & \\ & \text { (from 0 } \\ & \text { fewer to } \\ & 126 \\ & \text { more) }\end{array}$

not serious not
serious not serious not serious none

$\begin{array}{ll}396 / 459 & 722 / 906 \\ (86.3 \%) & (79.7 \%)\end{array}$

\section{C}

$\begin{array}{lll}\text { RR 1.08 } & \begin{array}{l}64 \text { more } \\ \text { per }\end{array} & \Theta \\ (1.01 \text { to } & 1,000 & \vdash \\ 1.15) & & \\ & \text { (from 8 } & \\ & \text { more to } \\ & 120 \\ & \text { more) }\end{array}$

Improvement in hemoglobin level

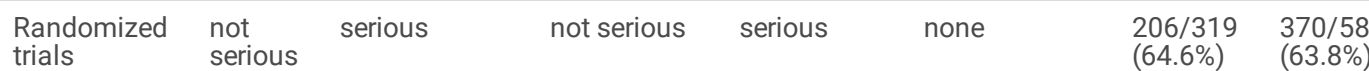

$(54.4 \%)$

$(20.5 \%)$

Adverse event (Hot flush)

\begin{tabular}{|c|c|c|c|c|c|c|c|c|c|c|c|}
\hline 5 & $\begin{array}{l}\text { Randomized } \\
\text { trials }\end{array}$ & $\begin{array}{l}\text { not } \\
\text { serious }\end{array}$ & not serious & not serious & serious $^{a}$ & none & $\begin{array}{l}258 / 474 \\
(54.4 \%)\end{array}$ & $\begin{array}{l}190 / 929 \\
(20.5 \%)\end{array}$ & $\begin{array}{l}\text { RR } 2.67 \\
(2.30 \text { to } \\
3.10)\end{array}$ & $\begin{array}{l}342 \\
\text { more per } \\
1,000 \\
\text { (from } \\
266 \\
\text { more to } \\
429 \\
\text { more) }\end{array}$ & $\begin{array}{l}\Theta \\
\Lambda\end{array}$ \\
\hline \multicolumn{12}{|c|}{ Uterine volume } \\
\hline 5 & $\begin{array}{l}\text { Randomized } \\
\text { trials }\end{array}$ & $\begin{array}{l}\text { not } \\
\text { serious }\end{array}$ & serious $^{b}$ & not serious & not serious & none & 422 & 828 & - & $\begin{array}{l}\text { MD } \\
17.47 \\
\text { lower } \\
\text { (27.54 } \\
\text { lower to } \\
7.4 \\
\text { lower) }\end{array}$ & $\theta$ \\
\hline \multicolumn{12}{|c|}{ Fibroid volume } \\
\hline 5 & $\begin{array}{l}\text { Randomized } \\
\text { trials }\end{array}$ & $\begin{array}{l}\text { not } \\
\text { serious }\end{array}$ & not serious & not serious & not serious & none & 408 & 800 & - & $\begin{array}{l}\text { MD } \\
23.18 \\
\text { lower } \\
\text { (28.98 } \\
\text { lower to } \\
17.38 \\
\text { lower) }\end{array}$ & $\begin{array}{l}\epsilon \\
\vdash\end{array}$ \\
\hline \multicolumn{12}{|c|}{ Symptom severity } \\
\hline 5 & $\begin{array}{l}\text { Randomized } \\
\text { trials }\end{array}$ & $\begin{array}{l}\text { not } \\
\text { serious }\end{array}$ & not serious & not serious & not serious & none & 429 & 859 & - & $\begin{array}{l}\text { MD } 9.05 \\
\text { lower } \\
\text { (9.68 } \\
\text { lower to } \\
8.43 \\
\text { lower) }\end{array}$ & $\theta$ \\
\hline
\end{tabular}

\begin{tabular}{|c|c|c|c|c|c|c|c|c|c|c|c|}
\hline 5 & $\begin{array}{l}\text { Randomized } \\
\text { trials }\end{array}$ & $\begin{array}{l}\text { not } \\
\text { serious }\end{array}$ & not serious & not serious & serious $^{a}$ & none & $\begin{array}{l}258 / 474 \\
(54.4 \%)\end{array}$ & $\begin{array}{l}190 / 929 \\
(20.5 \%)\end{array}$ & $\begin{array}{l}\text { RR } 2.67 \\
(2.30 \text { to } \\
3.10)\end{array}$ & $\begin{array}{l}342 \\
\text { more per } \\
1,000 \\
\text { (from } \\
266 \\
\text { more to } \\
429 \\
\text { more) }\end{array}$ & $\begin{array}{l}\Theta \\
\Lambda\end{array}$ \\
\hline \multicolumn{12}{|c|}{ Uterine volume } \\
\hline 5 & $\begin{array}{l}\text { Randomized } \\
\text { trials }\end{array}$ & $\begin{array}{l}\text { not } \\
\text { serious }\end{array}$ & serious $^{b}$ & not serious & not serious & none & 422 & 828 & - & $\begin{array}{l}\text { MD } \\
17.47 \\
\text { lower } \\
\text { (27.54 } \\
\text { lower to } \\
7.4 \\
\text { lower) }\end{array}$ & $\theta$ \\
\hline \multicolumn{12}{|c|}{ Fibroid volume } \\
\hline 5 & $\begin{array}{l}\text { Randomized } \\
\text { trials }\end{array}$ & $\begin{array}{l}\text { not } \\
\text { serious }\end{array}$ & not serious & not serious & not serious & none & 408 & 800 & - & $\begin{array}{l}\text { MD } \\
23.18 \\
\text { lower } \\
\text { (28.98 } \\
\text { lower to } \\
17.38 \\
\text { lower) }\end{array}$ & $\begin{array}{l}\epsilon \\
\vdash\end{array}$ \\
\hline \multicolumn{12}{|c|}{ Symptom severity } \\
\hline 5 & $\begin{array}{l}\text { Randomized } \\
\text { trials }\end{array}$ & $\begin{array}{l}\text { not } \\
\text { serious }\end{array}$ & not serious & not serious & not serious & none & 429 & 859 & - & $\begin{array}{l}\text { MD } 9.05 \\
\text { lower } \\
\text { (9.68 } \\
\text { lower to } \\
8.43 \\
\text { lower) }\end{array}$ & $\theta$ \\
\hline
\end{tabular}

Health-related quality of life 


\begin{tabular}{|c|c|c|c|c|c|c|c|c|c|c|c|}
\hline \multicolumn{7}{|c|}{ Certainty assessment } & \multicolumn{2}{|c|}{ No of patients } & \multicolumn{2}{|l|}{ Effect } & \multirow[t]{2}{*}{ C } \\
\hline $\begin{array}{l}\text { No of } \\
\text { studies }\end{array}$ & $\begin{array}{l}\text { Study } \\
\text { design }\end{array}$ & $\begin{array}{l}\text { Risk of } \\
\text { bias }\end{array}$ & Inconsistency & Indirectness & Imprecision & $\begin{array}{l}\text { Other } \\
\text { consideration }\end{array}$ & Elagolix & $\begin{array}{l}\text { Elagolix with } \\
\text { estradiol plus } \\
\text { norethindrone } \\
\text { acetate }\end{array}$ & $\begin{array}{l}\text { Relative } \\
\text { (95\% } \\
\text { Cl) }\end{array}$ & $\begin{array}{l}\text { Absolute } \\
(95 \% \mathrm{Cl})\end{array}$ & \\
\hline 5 & $\begin{array}{l}\text { Randomized } \\
\text { trials }\end{array}$ & $\begin{array}{l}\text { not } \\
\text { serious }\end{array}$ & very serious $^{c}$ & not serious & not serious & none & 428 & 859 & - & $\begin{array}{l}\text { MD } 9.94 \\
\text { higher } \\
(5.82 \\
\text { higher to } \\
14.06 \\
\text { higher })\end{array}$ & $\theta$ \\
\hline \multicolumn{12}{|c|}{ Bone mineral density (Lumbar spine) } \\
\hline 4 & $\begin{array}{l}\text { Randomized } \\
\text { trials }\end{array}$ & $\begin{array}{l}\text { Not } \\
\text { serious }\end{array}$ & Not serious & Not serious & Serious & none & 362 & 764 & - & $\begin{array}{l}\text { MD 2.63 } \\
\text { lower } \\
(3.12 \\
\text { lower to } \\
2.14 \\
\text { lower) }\end{array}$ & $\begin{array}{l}\Theta \\
\Lambda\end{array}$ \\
\hline \multicolumn{12}{|c|}{ Bone mineral density (Total hip) } \\
\hline 4 & $\begin{array}{l}\text { Randomized } \\
\text { trials }\end{array}$ & $\begin{array}{l}\text { Not } \\
\text { serious }\end{array}$ & Not serious & Not serious & Serious & none & 362 & 764 & - & $\begin{array}{l}\text { MD } 1.93 \\
\text { lower } \\
(2.56 \\
\text { lower to } \\
1.31 \\
\text { lower })\end{array}$ & $\begin{array}{l}\Theta \\
v\end{array}$ \\
\hline \multicolumn{12}{|c|}{ Bone mineral density (Femoral neck) } \\
\hline 4 & $\begin{array}{l}\text { Randomized } \\
\text { trials }\end{array}$ & $\begin{array}{l}\text { Not } \\
\text { serious }\end{array}$ & Not serious & Not serious & Serious & none & 362 & 764 & - & $\begin{array}{l}\text { MD } 0.77 \\
\text { lower } \\
(1.84 \\
\text { lower t0 } \\
0.3 \\
\text { higher) }\end{array}$ & $\theta$ \\
\hline
\end{tabular}

Table 6

Summary of findings, including GRADE quality assessment for the comparison between elagolix and elagolix with estradiol/norethindrone acetate by

\begin{tabular}{|c|c|c|c|c|c|c|c|c|}
\hline \multicolumn{2}{|c|}{ Outcome/Subgroup } & $\begin{array}{l}\text { No of } \\
\text { trials }\end{array}$ & $\begin{array}{l}\text { No of } \\
\text { participants }\end{array}$ & $\begin{array}{l}\text { Risk Ratio } \\
\text { (RR) }\end{array}$ & $\begin{array}{l}95 \% \text { Confidence } \\
\text { interval (Cl) }\end{array}$ & $\begin{array}{l}P \\
\text { value }\end{array}$ & $\begin{array}{l}\text { Random effect; }\left.\right|^{2} \\
\text { statistic }\end{array}$ & $\begin{array}{l}\text { GRADE } \\
\text { quality }\end{array}$ \\
\hline \multicolumn{9}{|c|}{ Reduction of menstrual blood loss of less than $80 \mathrm{ml}$} \\
\hline \multirow[t]{2}{*}{$\begin{array}{l}\text { Dosage of } \\
\text { E2/NETA }\end{array}$} & $\begin{array}{l}0.5 \mathrm{mg} \text { E2/ } 0.1 \mathrm{mg} \\
\text { NETA }\end{array}$ & 2 & 333 & 1.08 & $0.92,1.27$ & $\begin{array}{l}P= \\
0.350\end{array}$ & $52 \%$ & Moderate \\
\hline & $\begin{array}{l}1.0 \mathrm{mg} \text { E2/ } 0.5 \mathrm{mg} \\
\text { NETA }\end{array}$ & 4 & 1165 & 1.08 & $1.00,1.18$ & $\begin{array}{l}P= \\
0.060\end{array}$ & $58 \%$ & Moderate \\
\hline \multirow[t]{2}{*}{ Uterine volume } & $<500 \mathrm{~cm}^{3}$ & 3 & 894 & 1.07 & $0.95,1.21$ & $\begin{array}{l}P= \\
0.250\end{array}$ & $70 \%$ & Low \\
\hline & $>500 \mathrm{~cm}^{3}$ & 2 & 471 & 1.08 & $0.94,1.24$ & $\begin{array}{l}P= \\
0.290\end{array}$ & $46 \%$ & Moderate \\
\hline \multicolumn{9}{|c|}{ Reduction of more than $50 \%$ menstrual blood loss } \\
\hline \multirow[t]{2}{*}{$\begin{array}{l}\text { Dosage of } \\
\text { E2/NETA }\end{array}$} & $\begin{array}{l}0.5 \mathrm{mg} \text { E2/ } 0.1 \mathrm{mg} \\
\text { NETA }\end{array}$ & 2 & 333 & 1.10 & $1.01,1.19$ & $\begin{array}{l}P= \\
0.020\end{array}$ & $0 \%$ & Moderate \\
\hline & $\begin{array}{l}1.0 \mathrm{mg} \text { E2/ } 0.5 \mathrm{mg} \\
\text { NETA }\end{array}$ & 4 & 1165 & 1.08 & $0.99,1.17$ & $\begin{array}{l}P= \\
0.070\end{array}$ & $56 \%$ & Moderate \\
\hline \multirow[t]{2}{*}{ Uterine volume } & $<500 \mathrm{~cm}^{3}$ & 3 & 894 & 1.07 & $0.95,1.21$ & $\begin{array}{l}P= \\
0.250\end{array}$ & $70 \%$ & Low \\
\hline & $>500 \mathrm{~cm}^{3}$ & 2 & 471 & 1.10 & $1.02,1.17$ & $\begin{array}{l}P= \\
0.009\end{array}$ & $0 \%$ & Moderate \\
\hline
\end{tabular}

Foe secondary outcomes, there was no difference improvement in hemoglobin level between elagolix $\left(\mathrm{RR} 0.99,95 \% \mathrm{Cl} 0.80\right.$ to $1.22 ; \mathrm{I}^{2}$ statistic $=68 \%$; $\mathrm{P}=0.930$; five trials, 899 participants; low quality evidence) (27-30) and elagolix with estradiol/norethindrone acetate. However, elagolix has reduced mean percentage change in uterine volume (MD -17.47, 95\% Cl -27.54 to -7.40; $I^{2}$ statistic = 58\%; $\mathrm{P}<0.001$; five trials, 1250 participants; moderate quality evidence) (27-30), fibroid volume (MD -23.18, 95\% Cl-28.98 to -17.38; $I^{2}$ statistic $=0 \% ; \mathrm{P}<0.001$; five trials, 1208 participants; high quality evidence) (27-30), symptoms severity (MD $-9.05,95 \% \mathrm{Cl}-9.68$ to $-8.43 ; \mathrm{I}^{2}$ statistic $=0 \% ; \mathrm{P}<0.001$; five trials, 1288 participants; high quality evidence) $(27-30)$, and increased health-related quality of 
life (MD 9.94, 95\% Cl 5.82 to 14.06; I $^{2}$ statistic = 76\%; P < 0.001; five trials, 1287 participants; low quality evidence) (27-30) (Additional File 1, Table 5) compared to elagolix with estradiol/norethindrone acetate.

Elagolix has reduced bone mineral density in the lumbar spine (MD $-2.63,95 \% \mathrm{Cl}-3.12$ to $-2.14 ; \mathrm{I}^{2}$ statistic $=49 \%$; $\mathrm{P}<0.001$; four trials, 1126 participants; moderate quality evidence (28-30), and total hip (MD -1.93, 95\% Cl -2.56 to $-1.31 ; I^{2}$ statistic $=75 \%$; $\mathrm{P}<0.001$; four trials, 1126 participants; very low quality evidence) (28-30) except femoral neck (MD $-0.77,95 \% \mathrm{Cl}-1.84$ to $0.30 ; I^{2}$ statistic $=78 \% ; \mathrm{P}=0.160$; four trials, 1126 participants; very low quality evidence) (28-30) (Fig. 10, Table 5) compared to elagolix with estradiol/norethindrone acetate.

There was no difference of severe, serious or adverse event led to discontinuation between elagolix treatment and elagolix with estradiol/norethindrone acetate. Elagolix has increased the number of patients with side effect of hot flush (RR $2.67,95 \% \mathrm{Cl} 2.30$ to $3.10 ; I^{2}$ statistic $=0 \%$; $\mathrm{P}<0.001 ;$ five trials, 1403 participants; moderate quality evidence) (27-30), reduced the number of patients with risk of nausea $\left(\mathrm{RR} 0.63,95 \% \mathrm{Cl} 0.43\right.$ to $0.91 ; \mathrm{I}^{2}$ statistic $=0 \%$; $\mathrm{P}=0.010$; five trials, 1403 participants; low quality evidence) (27-30) and fatigue (RR $0.43,95 \% \mathrm{Cl} 0.23$ to $0.80 ;\left.\right|^{2}$ statistic $=0 \% ; \mathrm{P}=0.008 ;$ five trials, 1403 participants; low quality evidence) (27-30) (Fig. 11, Table 7) compared to elagolix with estradiol/norethindrone acetate.

Table 7

Summary of findings, including GRADE quality assessment for comparison between elagolix and elagolix with estradiol/norethindrone acetate by adverse

\begin{tabular}{|c|c|c|c|c|c|c|c|}
\hline Adverse event & $\begin{array}{l}\text { No of } \\
\text { trials }\end{array}$ & $\begin{array}{l}\text { No of } \\
\text { participants }\end{array}$ & $\begin{array}{l}\text { Risk Ratio } \\
\text { (RR) }\end{array}$ & $\begin{array}{l}95 \% \text { Confidence interval } \\
\text { (Cl) }\end{array}$ & $P$ value & $\begin{array}{l}\text { Random effect; }\left.\right|^{2} \\
\text { statistic }\end{array}$ & $\begin{array}{l}\text { GRADE } \\
\text { quality }\end{array}$ \\
\hline Any $A E$ & 5 & 1403 & 1.13 & $1.03,1.25$ & $\begin{array}{l}P= \\
0.010\end{array}$ & $68 \%$ & Moderate \\
\hline Serious AE & 5 & 1403 & 1.23 & $0.68,2.24$ & $\begin{array}{l}P= \\
0.500\end{array}$ & $0 \%$ & Low \\
\hline Severe AE & 4 & 979 & 0.90 & $0.45,1.83$ & $\begin{array}{l}P= \\
0.780\end{array}$ & $51 \%$ & Low \\
\hline $\begin{array}{l}\text { AE led to } \\
\text { discontinuation }\end{array}$ & 5 & 1403 & 1.31 & $0.92,1.87$ & $\begin{array}{l}P= \\
0.130\end{array}$ & $0 \%$ & Low \\
\hline Hot flush & 5 & 1403 & 2.67 & $2.30,3.10$ & $\begin{array}{l}P< \\
0.001\end{array}$ & $0 \%$ & Moderate \\
\hline Headache & 5 & 1403 & 1.16 & $0.84,1.62$ & $\begin{array}{l}P= \\
0.370\end{array}$ & $22 \%$ & Low \\
\hline Abdominal pain & 2 & 493 & 1.02 & $0.14,7.47$ & $\begin{array}{l}P= \\
0.990\end{array}$ & $47 \%$ & Low \\
\hline Dizziness & 2 & 493 & 0.87 & $0.38,2.02$ & $\begin{array}{l}P= \\
0.750\end{array}$ & $0 \%$ & Low \\
\hline Nausea & 5 & 1403 & 0.63 & $0.43,0.91$ & $\begin{array}{l}P= \\
0.010\end{array}$ & $0 \%$ & Low \\
\hline Fatigue & 5 & 1403 & 0.43 & $0.23,0.80$ & $\begin{array}{l}P= \\
0.008\end{array}$ & $0 \%$ & Low \\
\hline Hypertension & 3 & 809 & 0.60 & $0.23,1.59$ & $\begin{array}{l}P= \\
0.300\end{array}$ & $0 \%$ & Low \\
\hline
\end{tabular}

\section{Discussion}

This review was designed to include all randomized controlled trials that addressed the efficacy of elagolix treatment in women with heavy menstrual blood loss associated with uterine fibroid. The four identified trials formed comparisons either with placebo or with elagolix and estradiol/norethindrone acetate. The result showed that elagolix treatment increased the number of patients who had menstrual blood loss of less than $80 \mathrm{ml}$ or more than $50 \%$ reduction from baseline compared to placebo. However, there was no difference when elagolix was combined with estradiol/norethindrone acetate. Elagolix treatment also had reduced the mean percentage change in both fibroid and uterine volume in both comparisons.

The review showed more patients with improved hemoglobin level in elagolix treatment than placebo, but there was no difference in elagolix with estradiol/norethindrone acetate group. Elagolix also has reduced the severity of symptoms and increased the health-related quality of life in both comparisons. Nevertheless, more patients had adverse events such as hot flush, headache, and bone mineral density loss compared to placebo. Still, these hypoestrogenic effects were attenuated with the addition of estradiol/norethindrone acetate. In the subgroup analysis by dosage, frequency of drug administration, uterine volume, and fibroid volume, the high heterogeneity cannot be explained but has vanished in uterine volume $<500 \mathrm{~cm}^{3}$, fibroid volume $<$ $50 \mathrm{~cm}^{3}$, and low dose estradiol/norethindrone acetate.

\section{Overall completeness and applicability of evidence}

We had performed a comprehensive literature review to assess the effectiveness and role of elagolix in reducing heavy menstrual blood associated with uterine fibroid. We included four trials, but the results could apply to premenopausal women. Only one trial looked at the effects of elagolix over twelve months 
(30). Thus, the results of this study are limited in their applicability for long-term care. There were also insufficient trials for elagolix dose subgroup review. However, most trials used the formulation elagolix $300 \mathrm{mg}$ bd and $600 \mathrm{mg}$ qd (total $600 \mathrm{mg}$ daily). In all probability, these dosage forms can be used as therapy.

Elagolix had a good efficacy profile except for its hypoestrogenism side effects of hot flush, headache, and bone mineral density loss. However, these side effects can be reduced by combination with estradiol/norethindrone acetate. Women who are at risk of osteoporosis or on long-term prednisolone treatment may benefit from combination formulation therapy with no serious or life-threatening side effects.

\section{Quality of evidence}

The quality of trial evidence was variable. Generally, there was a low or unclear risk of bias for most trials in most domains. There was no evidence of selective reporting bias. The lack of adequate random sequence generation can lead to treatment effect bias in the original study and the subsequent review. All four trials were funded by AbbVie pharmaceutical. We had encountered moderate and high heterogeneity in most of our meta-analyses. The sensitivity analysis did not change the cumulative effect estimate. Some outcomes showed substantial heterogeneity. Therefore, the overall level of evidence contributing to this review is moderate to low quality. There was also a wide variation in the frequency of adverse events reported in the included studies due to definitions differences, difficulty in identifying and reporting adverse events.

\section{Potential biases in the review process}

We attempted to reduce publication bias by checking the reference lists of all related studies for further references and searching multiple databases without language restriction. However, we cannot be certain that we have located all the trials in this area. Since we have only four included trials, we could not construct a funnel plot for detecting bias or heterogeneity due to insufficient studies. All included trials had reported approximately almost all outcomes. Treatment periods differed in two trials $(27,30)$ but the outcome was unlikely to be influenced. The outcome was unlikely to be affected, although the process of randomization and allocation concealment were not stated in all trials.

All four included trials were funded and prospectively registered under clinicaltrial.gov. The primary outcome was measured using the well-established alkaline hematin method. Although all the studies showed the same direction of effect, we encountered moderate heterogeneity in our primary outcome. We were not able to explain this in our subgroup analysis. Other secondary outcomes were objectively assessed using standard measurement, for example, ultrasound, UFS-QoL questionnaire, and dual-energy x-ray absorptiometry scans. In two trials, women with asymptomatic anemia and a hemoglobin level of less than 12 $\mathrm{g} / \mathrm{dl}$ at screening or during the study period were recommended to take iron supplements. We were uncertain whether this could influence the hemoglobin level.

\section{Agreement and disagreements with other studies or review}

Two reviews include one on predictors of response for elagolix with estradiol/norethindrone acetate and the other on medical treatment of uterine fibroid (4, 23). Al-Hendy 2020 looked at independent variables of only one trial (29). This review found that elagolix with estradiol/norethindrone acetate successfully reduced heavy menstrual bleeding caused by uterine fibroids regardless of patients' age, body mass index, race, ethnicity, baseline menstrual blood loss, fibroid location, or uterine and primary fibroid volume. Sabry 2012 had reviewed the hormonal and nonhormonal treatment of uterine fibroid. Our review included three additional trials $(27,28,30)$. All four trials were related to our prespecified primary and secondary outcomes. The secondary outcome focused on bone mineral density loss, hemoglobin level improvement, symptoms' severity, and health-related quality of life, which are not covered in Al-Hendy 2020. The current review also focused on the hypoestrogenism side effect of elagolix that is attenuated with estradiol/norethindrone acetate.

\section{Conclusion}

Elagolix appears to be effective in reducing heavy menstrual bleeding caused by uterine fibroid in premenopausal women. It also has a beneficial effect on uterine and fibroid volume reduction. Furthermore, it reduces the severity of symptoms and improves the health-related quality of life. The hemoglobin level also improved with elagolix treatment, but this needs to be justified as the participants were given hematinic supplements at screening and during the treatment period. There were no severe or life-threatening adverse events that contributed to the discontinuation of the biosafety profile. Elagolix with estradiol/norethindrone acetate was effective in combating the hypoestrogenism side effects of hot flushes, headaches, and bone loss. Therefore, women at risk of osteoporosis should be treated with elagolix and estradiol/norethindrone acetate. As a result of this review, many women may be able to avoid surgical intervention with elagolix treatment, which later helps them preserve their fertility.

Data on the study design, setting, randomization method, and blinding should all be reported during the trial to increase the quality of evidence. If further research is done to look at the use of elagolix for uterine fibroid treatment, they would need to produce similar and longer trials with varying elagolix dosages and fibroid location. It helps with heterogeneity subgroup analysis. The importance of age-based inclusion criteria should be emphasized further. Participants only receive a hematinic supplement if they have moderate to severe or symptomatic anemia, to see actual changes in hemoglobin levels.

\section{Abbreviations}

GnRH: Gonadotropin-releasing hormone; US FDA: United States Food and Drug Administration; UFS-QoL: Uterine Fibroid Symptom and Quality of Life.

\section{Declarations}


We would like to thank librarian from Hamdan Tahir Library, for their assistance with database searches.

\section{Authors' Contributions}

YY and NMN conceived and designed the review, performed the review, analyzed the data, created figures and/or tables, authored or reviewed drafts of the paper, and approved the final draft. JM and IA conceived and designed the review, performed the review, authored or reviewed drafts of the paper, and approved the final draft. All authors have read and approved the manuscript.

\section{Funding}

The authors received no funding for this work.

\section{Availability of data and materials}

The datasets generated during and /or analysed during the current study are available in the [Additional File 1,2 and 3] repository, [https://doi.org/10.6084/m9.figshare.15034881.v1].

\section{Ethics approval and consent to participate}

Not applicable.

\section{Consent for publication}

Not applicable.

\section{Competing interest}

The authors declare there are no competing interests.

\section{References}

1. Fleischer R, Weston GC, Vollenhoven BJ, Rogers PAW. Pathophysiology of fibroid disease: angiogenesis and regulation of smooth muscle proliferation. Best Practice \& Research Clinical Obstetrics \& Gynaecology. 2008;22(4):603-14.

2. Stewart EA. Uterine fibroids. The Lancet. 2001;357(9252):293-8.

3. Neri M, Melis GB, Giancane E, Vallerino V, Pilloni M, Piras B, et al. Clinical utility of elagolix as an oral treatment for women with uterine fibroids: A short report on the emerging efficacy data. International Journal of Women's Health. 2019;11:535-46.

4. Sabry M, Al-Hendy A. Medical treatment of uterine leiomyoma. Reproductive Sciences. 2012;19(4):339-53.

5. Erica E. Marsh AA-H, Dale Kappus, Alex Galitsky, Elizabeth A. Stewart, and Majid Kerolous. Burden, prevalence, and treatment of uterine fibroids: A survey of U.S. women. Journal of Women's Health. Nov 2018.;27(11):1359-67.

6. Fuldeore MJ, Soliman AM. Patient-reported prevalence and symptomatic burden of uterine fibroids among women in the United States: findings from a cross-sectional survey analysis. International journal of women's health. 2017;9:403-11.

7. Cramer SF, Patel A. The frequency of uterine leiomyomas. American journal of clinical pathology. 1990;94(4):435-8.

8. Nowak RA. Fibroids: pathophysiology and current medical treatment. Best Practice \& Research Clinical Obstetrics \& Gynaecology. 1999;13(2):223-38.

9. ElKafas H, Ali M, Al-Hendy A. Leiomyomas. In: Skinner MK, editor. Encyclopedia of reproduction (Second edition). Oxford: Academic Press; 2018. p. 1015.

10. Fantasia HC. Elagolix as a novel treatment for endometriosis-related pain. Nursing for Women's Health. 2019;23(4):366-9.

11. Barra F, Vitale SG, Seca M, Scala C, Leone Roberti Maggiore U, Cianci A, et al. The potential role of elagolix for treating uterine bleeding associated to uterine myomas. Expert opinion on pharmacotherapy. 2020;21(12):1419-30.

12. Finch AR, Caunt CJ, Armstrong SP, McArdle CA. Agonist-induced internalization and downregulation of gonadotropin-releasing hormone receptors. Am J Physiol Cell Physiol. 2009;297(3):C591-C600.

13. Griesinger G, Felberbaum R, Diedrich K. GnRH-antagonists in reproductive medicine. Archives of gynecology and obstetrics. 2005;273(2):71-8.

14. Nader A, Mostafa NM, Ali F, Shebley M. Drug-drug interaction studies of elagolix with oral and transdermal low-dose hormonal add-back therapy. Clinical pharmacokinetics. 2020.

15. Hallberg L, Hôgdahl A-M, Nilsson L, Rybo G. Menstrual blood loss-a population study. Acta Obstetricia et Gynecologica Scandinavica. 1966;45(3):32051.

16. Mawet M, Nollevaux F, Nizet D, Wijzen F, Gordenne V, Tasev N, et al. Impact of a new levonorgestrel intrauterine system, Levosert@, on heavy menstrual bleeding: results of a one-year randomised controlled trial. The European Journal of Contraception \& Reproductive Health Care. 2014;19(3):169-79.

17. Warner PE, Critchley HO, Lumsden MA, Campbell-Brown M, Douglas A, Murray GD. Menorrhagia I: measured blood loss, clinical features, and outcome in women with heavy periods: a survey with follow-up data. Am J Obstet Gynecol. 2004;190(5):1216-23.

18. Fraser IS, Warner P, Marantos PA. Estimating menstrual blood loss in women with normal and excessive menstrual fluid volume1 1 We acknowledge the substantial contributions of Gay McCarron, Tanya Resta, and Robert Markham to the execution of this study. Obstetrics \& Gynecology. 2001;98(5, Part 
1):806 - 14.

19. Higgins JP, Deeks JJ, Altman DG, Group obotCSM. Analysing data and undertaking meta-analyses. Cochrane Handbook for Systematic Reviews of Interventions2019. p. $241-84$.

20. RevMan. Review Manager (Computer program) Version 5.4 The Cochrane Collaboration 2020 [

21. Guyatt GH, Oxman AD, Vist GE, Kunz R, Falck-Ytter Y, Alonso-Coello P, et al. GRADE: an emerging consensus on rating quality of evidence and strength of recommendations. BMJ. 2008;336(7650):924-6.

22. Kim JH, Al-Hendy A, Archer DF, Barnhart K, Bradley LD, Feinberg E, et al. Clinical outcomes in elagolix-treated women with uterine fibroids who did not meet the study endpoint criteria in two phase 3 trials. Journal of Minimally Invasive Gynecology. 2020;27(7, Supplement):S49.

23. Al-Hendy A, Bradley L, Owens CD, Wang H, Barnhart KT, Feinberg E, et al. Predictors of response for elagolix with add-back therapy in women with heavy menstrual bleeding associated with uterine fibroids. American Journal of Obstetrics and Gynecology. 2020.

24. Polepally AR, Ng JW, Salem AH, Dufek MB, Parikh A, Carter DC, et al. Assessment of clinical drug-drug interactions of elagolix, a gonadotropin-releasing hormone receptor antagonist. Journal of clinical pharmacology. 2020;60(12):1606-16.

25. Muneyyirci-Delale O, Archer DF, Jeannie Kim JH, Liu R, Owens CD, Puscheck EE. Phase 3 trial results: efficacy and safety of elagolix in a subset of women with uterine fibroids and adenomyosis. Fertility and sterility. 2019;112(3):e4-.

26. Taylor HS, Bedaiwy MA, Lukes AS, Chwalisz K, Owens C, Bradley L. Efficacy and safety of elagolix in a subgroup of women with uterine fibroids and adenomyosis: results from a phase 2 trial. Fertility and Sterility. 2018;110(4, Supplement):e61.

27. Archer DF, Stewart EA, Jain RI, Feldman RA, Lukes AS, North JD, et al. Elagolix for the management of heavy menstrual bleeding associated with uterine fibroids: results from a phase 2a proof-of-concept study. Fertility and sterility. 2017;108(1):152-60.e4.

28. Carr BR, Stewart EA, Archer DF, Al-Hendy A, Bradley L, Watts NB, et al. Elagolix alone or with add-back therapy in women with heavy menstrual bleeding and uterine leiomyomas: a randomized controlled trial. Obstetrics and gynecology. 2018;132(5):1252-64.

29. Schlaff WD, Ackerman RT, Al-Hendy A, Archer DF, Barnhart KT, Bradley LD, et al. Elagolix for heavy menstrual bleeding in women with uterine fibroids. New England Journal of Medicine. 2020;382(4):328-40.

30. Simon JA, Al-Hendy A, Archer DF, Barnhart KT, Bradley LD, Carr BR, et al. Elagolix treatment for up to 12 months in women with heavy menstrual bleeding and uterine leiomyomas. Obstetrics and gynecology. 2020;135(6):1313-26.

31. Mansfield PK, Voda A, Allison G. Validating a pencil-and-paper measure of perimenopausal menstrual blood loss. Women's Health Issues. 2004;14(6):242-7.

\section{Figures}

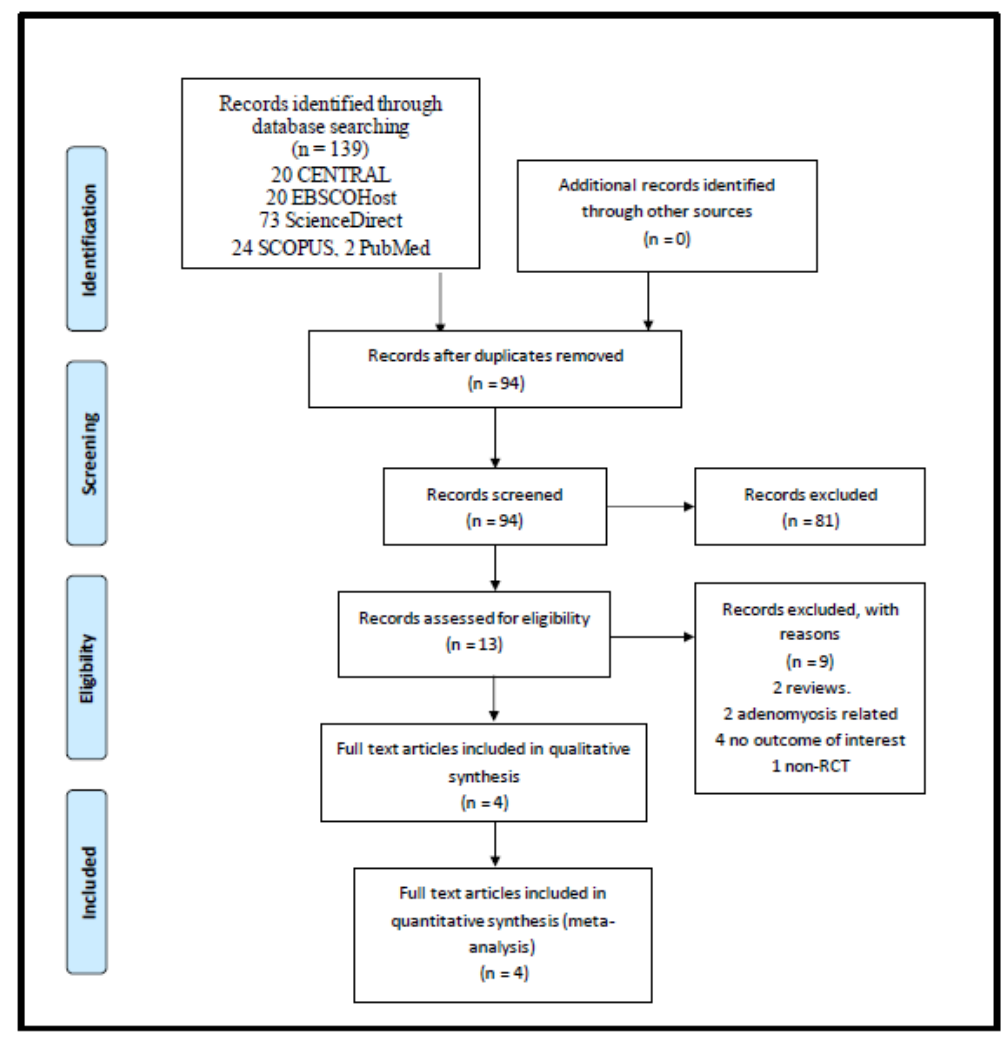

Figure 1

PRISMA flow diagram 


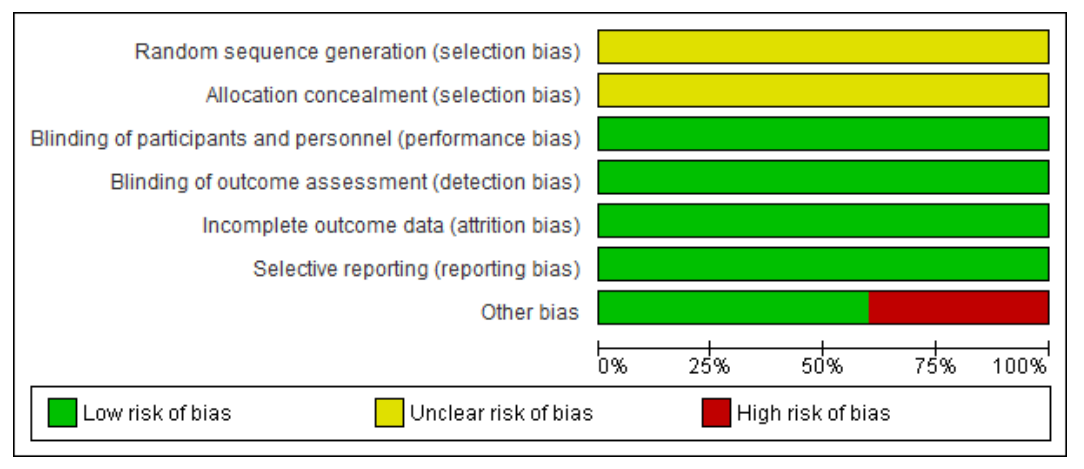

Figure 2

'Risk of bias' graph: review authors' judgements about each risk of bias item presented as percentages across all included studies

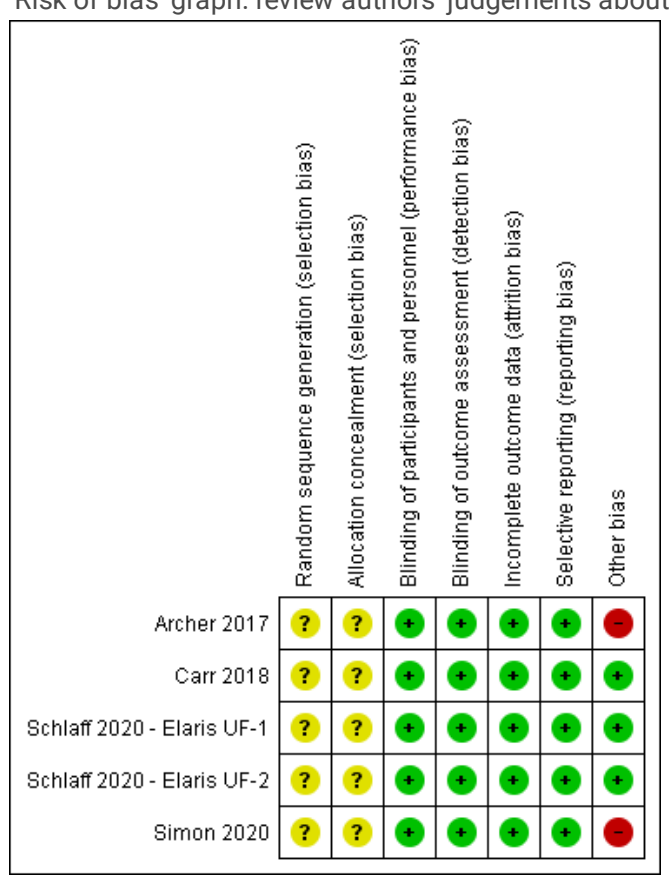

Figure 3

'Risk of bias' summary: review authors' judgements about each risk of bias item for each included study

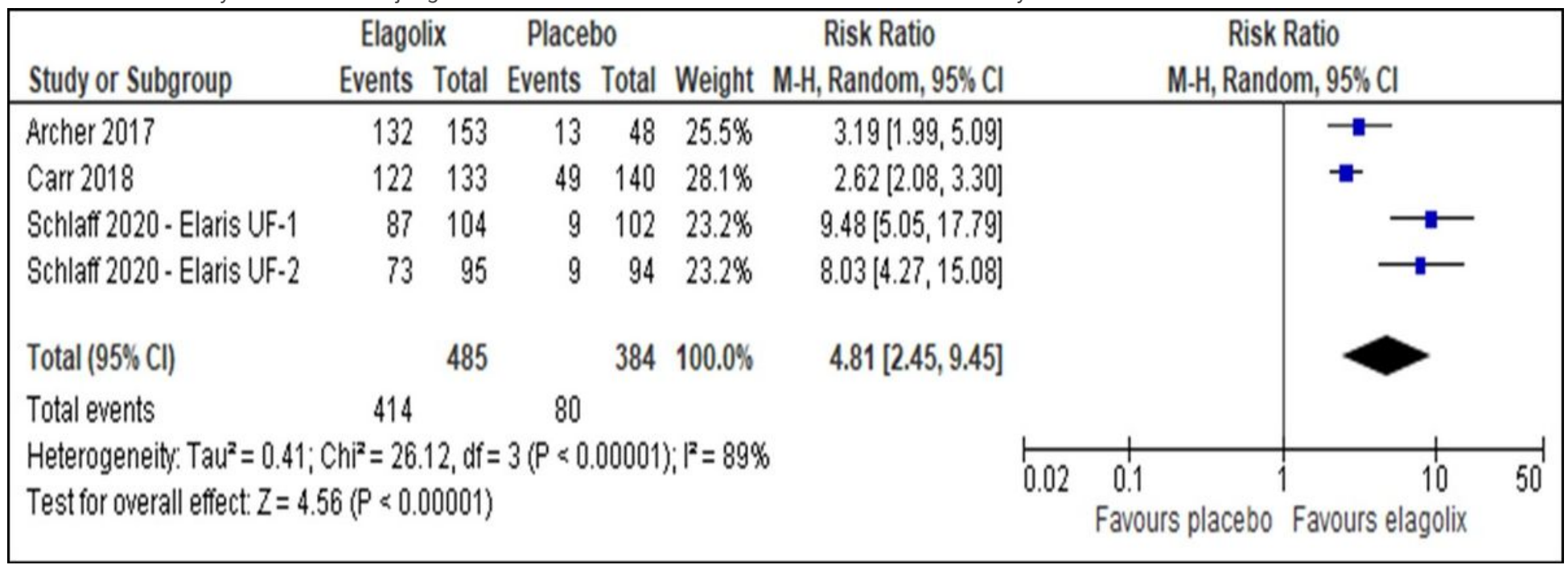

Figure 4

Comparison between elagolix and placebo for the outcome reduction of menstrual blood loss of less than $80 \mathrm{ml}$ 


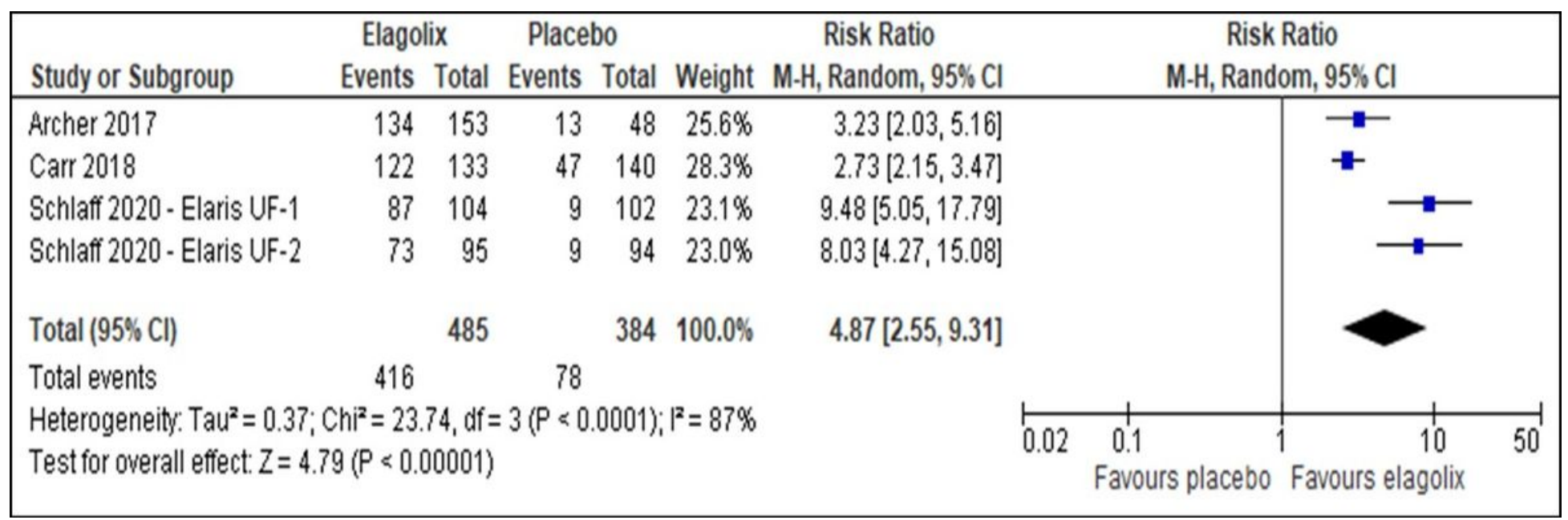

Figure 5

Comparison between elagolix and placebo for the outcome reduction of menstrual blood loss of more than $50 \%$

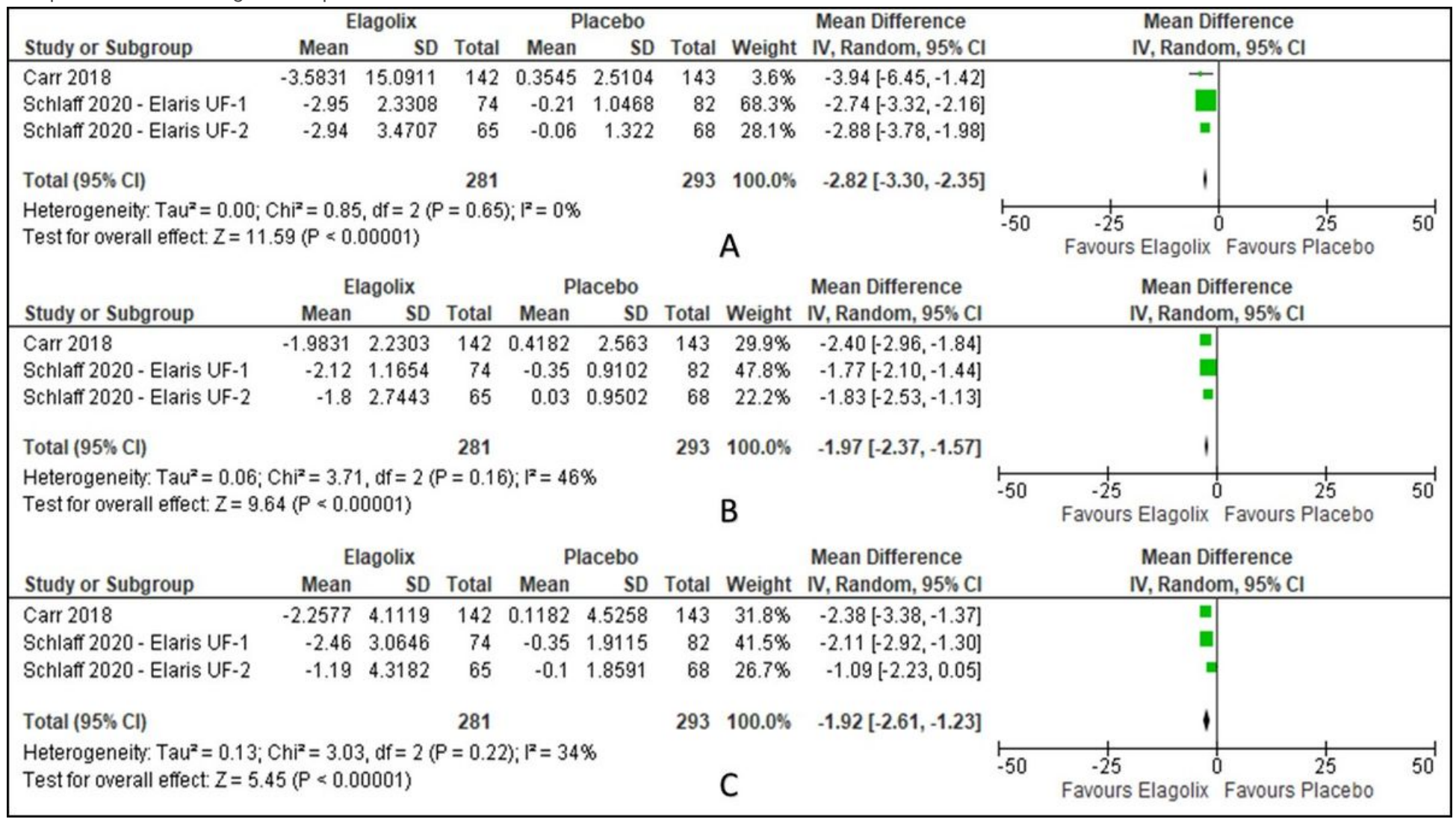

Figure 6

Comparison between elagolix and placebo for the outcome of bone mineral density (A: lumbar spine, B: total hip, C: femoral neck) 


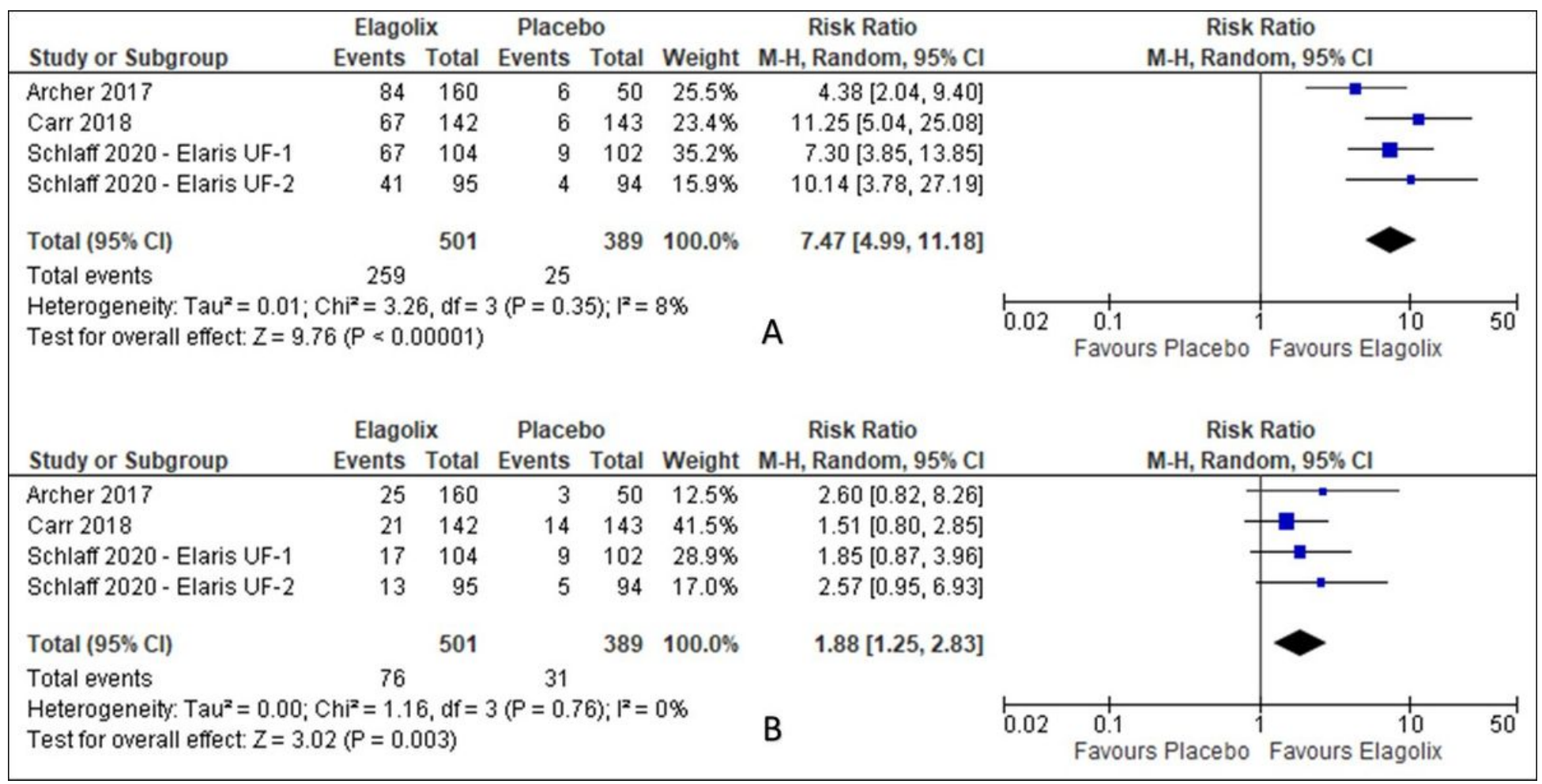

Figure 7

Comparison between elagolix and placebo for the outcome of adverse events (A: hot flush, B: headache)

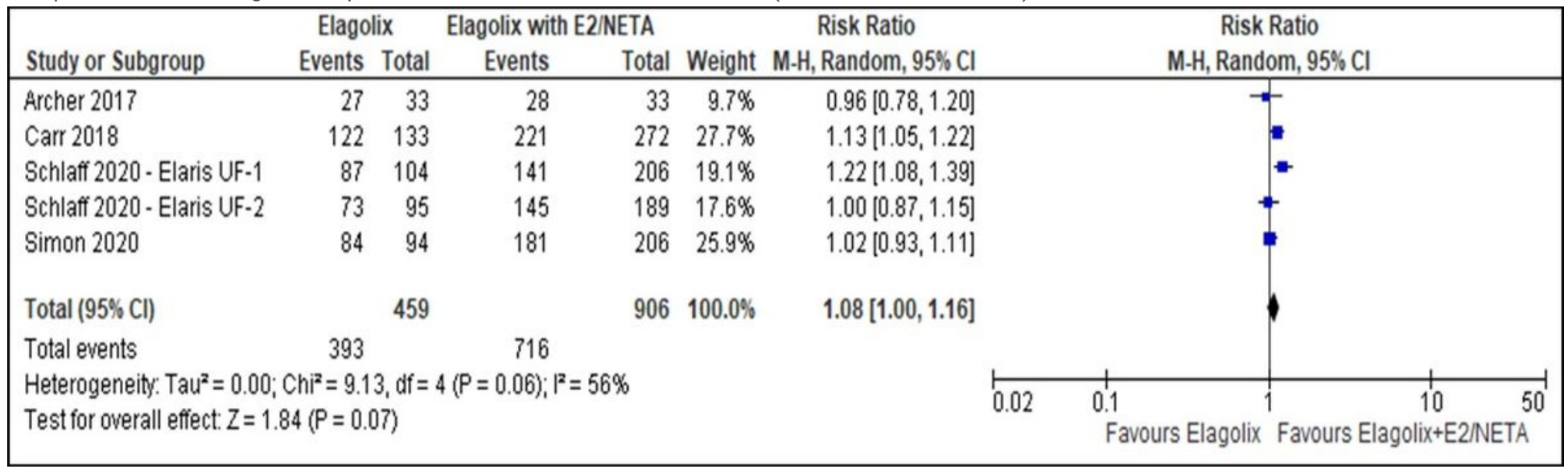

Figure 8

Comparison between elagolix and elagolix with estradiol/norethindrone acetate for the outcome reduction of menstrual blood loss of less than $80 \mathrm{ml}$

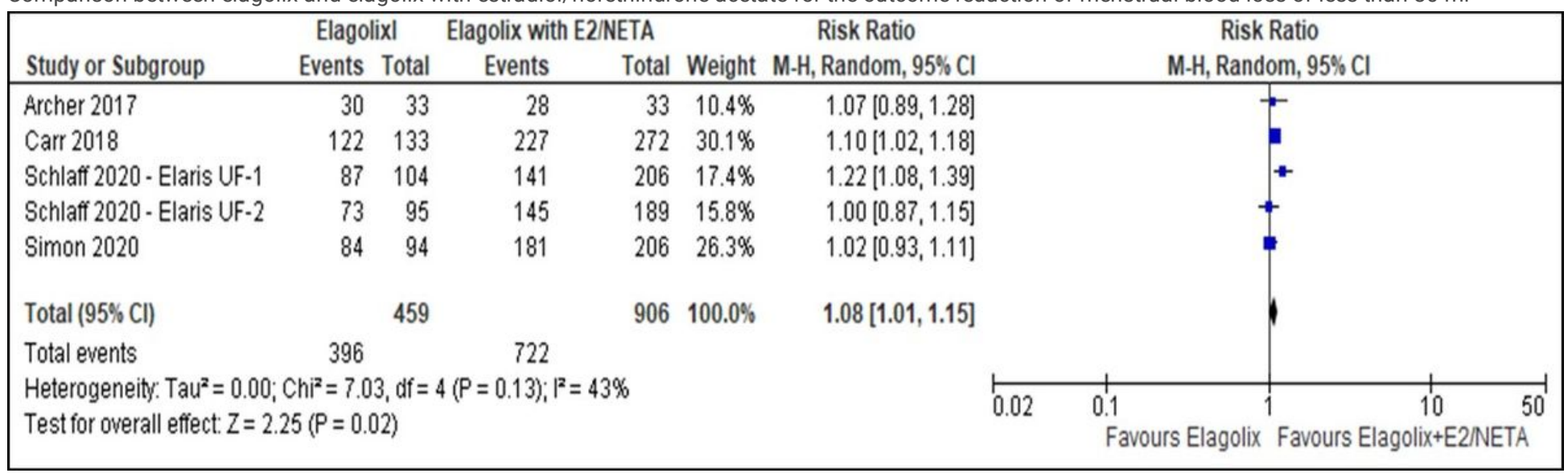

Figure 9 
Comparison between elagolix and elagolix with estradiol/norethindrone acetate for the outcome reduction of more than $50 \%$ menstrual blood loss

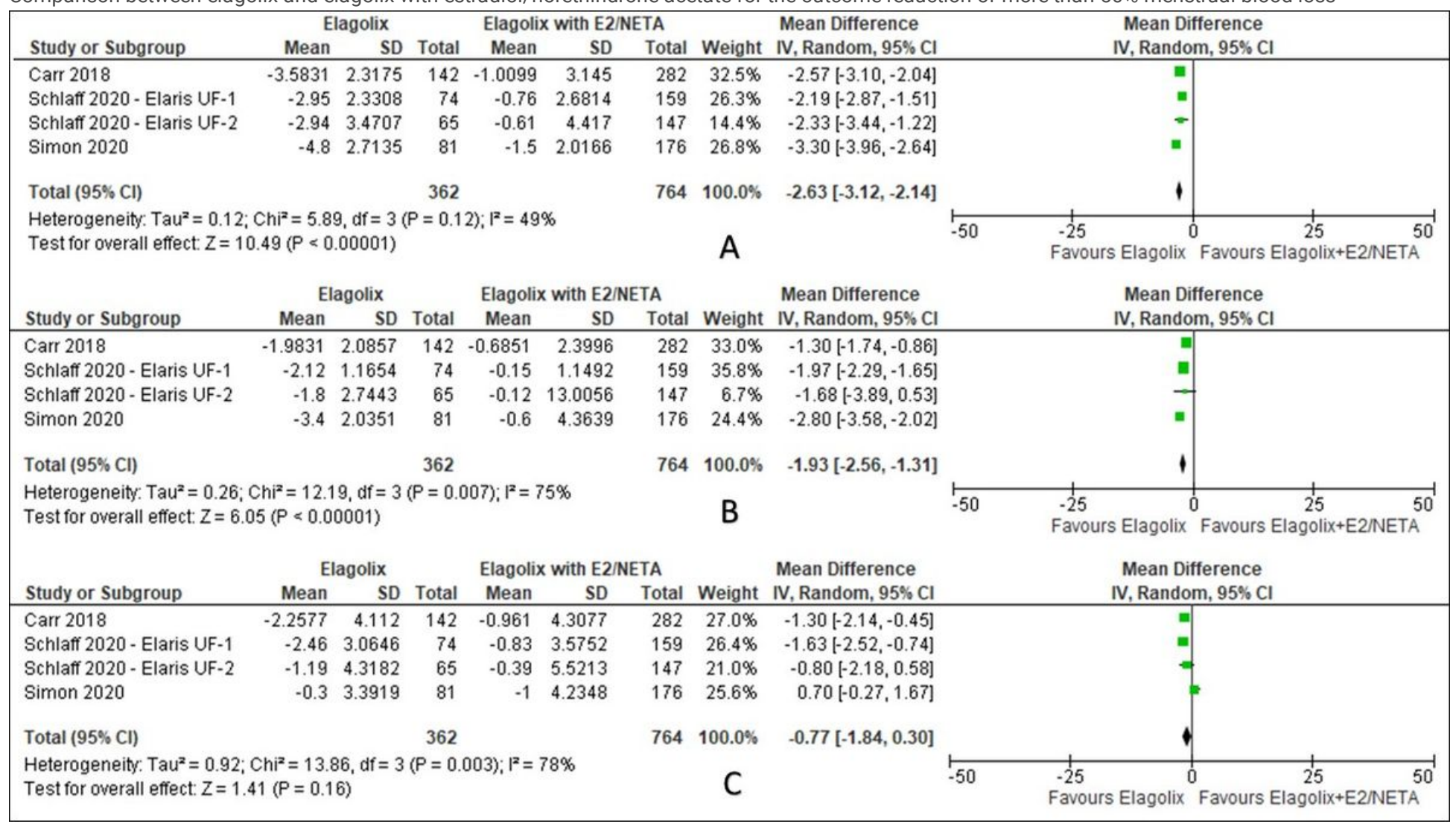

\section{Figure 10}

Comparison between elagolix and elagolix with estradiol/norethindrone acetate for the outcome of bone mineral density (A: lumbar spine, B: total hip, C: femoral neck) 


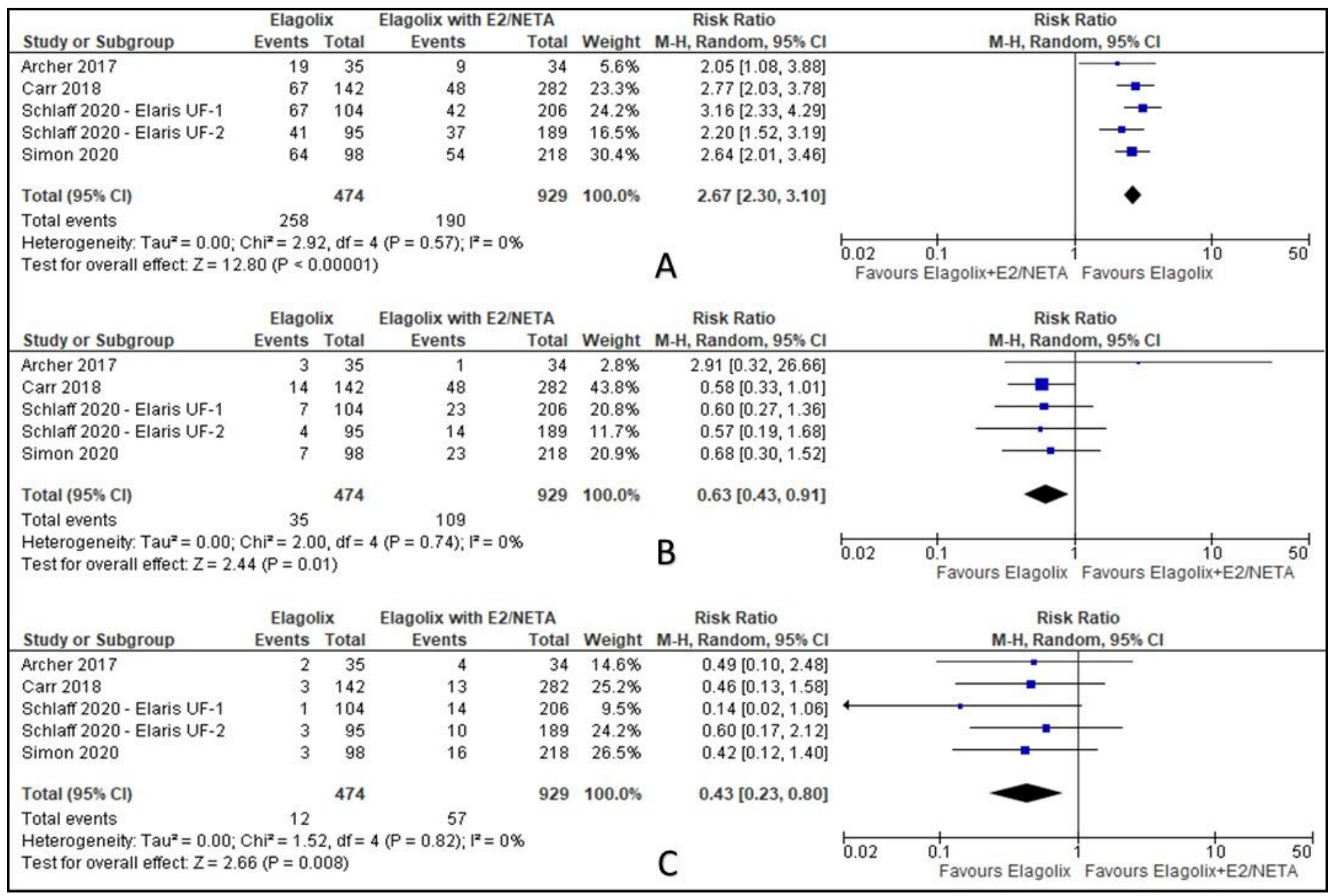

\section{Figure 11}

Comparison between elagolix and elagolix with estradiol/norethidrone acetate for the outcome adverse event (A: hot flush, B: nausea, C: fatigue)

\section{Supplementary Files}

This is a list of supplementary files associated with this preprint. Click to download.

- AdditionalFile1.docx

- AdditionalFile2.docx

- AdditionalFile3.docx 